\title{
Sintering Optimisation and Recovery of Aluminum and Sodium from Greek Bauxite Residue
}

\author{
Pritii Wai Yin Tam ${ }^{1,2, * \mathbb{C}}$, Dimitrios Panias ${ }^{2} \mathbb{D}$ and Vicky Vassiliadou ${ }^{1}$ \\ 1 Department of Continuous Improvement and Systems Management, Aluminum of Greece plant, \\ Metallurgy Business Unit, Mytilineos S.A., Agios Nikolaos, 32003 Boeotia, Greece; \\ vicky.vassiliadou@alhellas.gr \\ 2 School of Mining and Metallurgical Engineering, National Technical University of Athens, \\ 9, Iroon Polytechniou, Zografou Campus, 15780 Athens, Greece; panias@metal.ntua.gr \\ * Correspondence: pritiitam@yahoo.com; Tel.: +61-4-8109-0871
}

Received: 29 August 2019; Accepted: 19 September 2019; Published: 20 September 2019

\begin{abstract}
Bauxite residue is treated for the recovery of aluminum and sodium by sintering with the addition of soda, metallurgical coke and other reagents such as $\mathrm{CaO}, \mathrm{MgO}$ and $\mathrm{BaO}$. A thorough thermodynamic analysis using Factsage $7.0^{\mathrm{TM}}$ software was completed together with XRD mineralogy of sinters with different fluxes and reagents additions. Through both thermodynamic interpretation and mineralogical confirmations, it was observed that the type of desilication product in bauxite residue influences the total aluminum recovery through the sintering process and formation of sodium aluminum silicate exists in equilibrium with sodium aluminate, unless silica is consumed by additives (such as $\mathrm{CaO}, \mathrm{MgO}, \mathrm{BaO}$ etc.) forming other more thermodynamically favorable species and liberating alumina. Addition of barium oxide improves the aluminum and sodium recovery to $75 \%$ and $94 \%$ respectively. Complex sinter product formation that are triggered due to high calcium content in the Greek bauxite residue reduces aluminum recovery efficiency. Optimised and feasible recovery of aluminum and sodium for Greek bauxite residue was proved to be $70 \%$ and $85 \%$ respectively, when sintered with $50 \%$ excess stoichiometric soda. It was observed that stoichiometric carbon addition in inert atmosphere only assisted recovery up to $75 \%$ of aluminum and $83 \%$ of sodium, though there are benefits gained from pre-reducing iron from hematite for downstream recovery.
\end{abstract}

Keywords: bauxite residue; sintering; aluminum; sodium; recovery

\section{Introduction}

The aluminum sector has seen an increase of demand and production within the recent years with current annual estimate in 2017 being 132,390 thousand metric tonnes of alumina [1]. The global market shows no signs of reduction with China's competitive focus in alumina production estimated surpassing more than half of annual global production in 2017 [1]. Meanwhile, West Europe reports about 5,890,000 metric tonnes of alumina in 2017 with Aluminum of Greece contributing up to 820,000 metric tons of alumina in their yearly production [1,2]. However, as 1 tonne of alumina often generates about 1-1.5 tonnes of bauxite residue (BR) during its production in the Bayer process route, the uncertainty of effectively managing bauxite residue stockpiles in areas of increasingly tightening regulations has encouraged further research efforts into total valorization. Power, Klauber and Gräfe consolidated a series of papers that reviewed extensively towards methods of disposal, management and best practices as well as options in the interim that dealt with the reuse of bauxite residue $[3,4]$. They have also reported that from the period of 1964 to 2008, patents relating to bauxite residue filed in civil and building constructions consisted of about a third from the total amount, followed by around equal amounts of catalyst and adsorbent patents; ceramics, plastics, coating or pigments, 
and wastewater treatment. Steel and slag patents and the recovery of major metals were around $7 \%$ and $9 \%$ respectively. With recent years sustainable economy focus, minor elements in enriched secondary resource such as bauxite residue had gained larger traction in developing rare earth recovery processes [5-8].

It is reported that iron often found in the range of $5-60 \% \mathrm{Fe}_{2} \mathrm{O}_{3}$ depending on the mineral types influencing bauxite residue in Bayer processing, followed by $5-30 \%$ of $\mathrm{Al}_{2} \mathrm{O}_{3}, 3-50 \%$ of $\mathrm{SiO}_{2}$ and $0.3-15 \%$ of $\mathrm{TiO}_{2}$. Calcium and sodium averages about $2-14 \%$ of $\mathrm{CaO}$ and $1-10 \%$ of $\mathrm{Na}_{2} \mathrm{O}$ in bauxite residue. Calcium's addition also ranges from pre-desilication step, scales suppression up until mineral retardations and transformations [9,10]. Mishra and Gostu published a recent review into several different treatment options of the residue, with pyrometallurgical paths either involving smelting or sintering-type processing [11]. High temperature smelting of bauxite residue for complete iron reduction and removal and the subsequent conditioning of slag are commonly found in current researches [6,12-16]. The sintering or reductive-sintering of bauxite residue has also been explored in literature $[7,11,14,17-19]$, but inefficient separation of varied magnetic iron phases often hinders iron recovery. However, sintering and reductive-sintering are able to recover aluminum and sodium without suffering sodium gaseous losses when smelted at high temperatures.

As bauxites contain an amount of reactive silica that is soluble in caustic conditions of the Bayer process, desilication becomes necessary to reduce silica impurities and to avoid scale build-up within the evaporator and digester units. A desilication product that is often formed is a type of sodium aluminosilicate with a formula which may be represented as $\mathrm{Na}_{8}\left(\mathrm{AlSiO}_{4}\right)_{6} \mathrm{X}_{2} \cdot n \mathrm{H}_{2} \mathrm{O}$ where $\mathrm{X}$ could be $\frac{1}{2} \mathrm{CO}_{3}{ }^{2-}, \mathrm{Cl}^{-}, \mathrm{OH}^{-}$, and $\frac{1}{2} \mathrm{SO}_{4}{ }^{2-}[20,21]$. The sodium aluminosilicate product often exists as sodalite and cancrinite, expressed in similar stoichiometry, and sometimes substituting $\mathrm{Na}^{+}$with $\mathrm{K}^{+}$, $\mathrm{Ca}^{2+}, \mathrm{OH}^{-}, \mathrm{SO}_{4}{ }^{2-}, \mathrm{Cl}^{-}, \mathrm{CO}_{3}{ }^{2-}$ and $\mathrm{H}_{2} \mathrm{O}$ in its framework [20]. If calcium is inherently abundant in bauxite or if lime is added to aid the silica removal, tricalcium aluminate $\left(\mathrm{Ca}_{3} \mathrm{Al}_{2}(\mathrm{OH})_{12}\right)$ may also be formed within the Bayer liquor, which transforms into hydrogrossular or hydrogarnet type species $\left(\mathrm{Ca}_{3} \mathrm{Al}_{2}\left(\mathrm{SiO}_{4}\right)_{3-x}(\mathrm{OH})_{4 x}\right)$ [10]. Smith further characterizes the reactions and phase transformations that occur with lime's presence particularly in high temperature Bayer digestion condition. He observed that lime addition encourages sodium recovery, suppressing the sodalite form in favor of hydrogrossular products [10]. Rivera et al. adds that when bauxite residue is subjected to $\mathrm{CO}_{2}$ neutralisation, cancrinitic and grossular phases is stabilized with carbonate ions, thus reducing alkalinity [22]. Meanwhile, the simple aluminum-bearing minerals are often originated from the unreacted boehmitic $(\gamma-\mathrm{AlO}(\mathrm{OH}))$, diasporic $(\alpha-\mathrm{AlO}(\mathrm{OH}))$ and gibbsitic $\left(\gamma-\mathrm{Al}(\mathrm{OH})_{3}\right)$ minerals in bauxite ores. Through the addition of soda and metal oxides, coupled with also a possible reductive stage of iron by adding carbon, the aluminum-bearing minerals is then transformed into leachable sodium aluminate phase, while suppressing reactive silica formation. This will also allow ease of the introduction of leachates back again into the Bayer circuit.

\section{Previous Studies in Soda and Lime-Soda Sintering Processes}

Soda sintering or lime-soda sintering process, began from Louis Le Chatelier's work in 1855 in obtaining aluminum hydroxide $\left(\mathrm{Al}(\mathrm{OH})_{3}\right)$ from sintering bauxite with soda at around $1000{ }^{\circ} \mathrm{C}$ which forms a leachable sodium aluminate species [23]. It was further improved by introducing a calcination step to produce alumina $\left(\mathrm{Al}_{2} \mathrm{O}_{3}\right)$ from $\mathrm{Al}(\mathrm{OH})_{3}$. Deville-Pechiney process also introduced lime and coke into the sintering processes [24]. Therefore, soda often targets the aluminum-bearing mineral species into sodium aluminate, as described in Reactions (1-3).

$$
\begin{gathered}
2 \mathrm{AlOOH}+\mathrm{Na}_{2} \mathrm{CO}_{3} \rightarrow 2 \mathrm{NaAlO}_{2}+\mathrm{CO}_{2}+\mathrm{H}_{2} \mathrm{O} \\
2 \mathrm{Al}(\mathrm{OH})_{3}+\mathrm{Na}_{2} \mathrm{CO}_{3} \rightarrow 2 \mathrm{NaAlO}_{2}+\mathrm{CO}_{2}+3 \mathrm{H}_{2} \mathrm{O} \\
\mathrm{Na}_{6} \mathrm{Al}_{6} \mathrm{Si}_{6} \mathrm{O}_{24} \cdot 2 \mathrm{CaCO}_{3} \cdot n \mathrm{H}_{2} \mathrm{O}+\mathrm{Na}_{2} \mathrm{CO}_{3}+\mathrm{Fe}_{2} \mathrm{O}_{3}+10 \mathrm{CaO}=6 \mathrm{NaAlO}_{2}+6 \mathrm{Ca}_{2} \mathrm{SiO}_{4}+ \\
2 \mathrm{NaFeO}_{2}+3 \mathrm{CO}_{2}+n \mathrm{H}_{2} \mathrm{O} .
\end{gathered}
$$


Literature leaning towards Bayer process efficiency often targets leaching conditions in Bayer digestion and selectivity of aluminum precipitation species for activated alumina recovery, and from the by-product valorisation, the sintering of bauxite residues for the recovery of aluminum and sodium [25-28]. The scope of this work will be focused on the latter. Kaussen et al. explored a wide range of methods in recovering aluminum from bauxite residue in the Lünen landfill [14,29]. This expounded from secondary Bayer leaching at higher temperature and pressures in concentrated caustic solution [14], smelting to produce leachable calcium aluminate phases, sometimes coupled with concentrated caustic leaching again $[13,14]$, and soda/lime-soda sintering [14,19]. Here, along with many other studies [30-33], it is noted that sodium ferrite species and sodium titanate species are potentially transformed after sintering and leaching, into hematite and titanium oxide species respectively. The converted salts of other present impurities in bauxite residue do not affect the sodium recovery, with exception to sodium silicate which increases silica impurity into the leachate [29]. Bruckard et al. reports that a solid-solution series of sodium aluminate-carnegeite species formed when bauxite residue is treated at high temperatures of $1400{ }^{\circ} \mathrm{C}$ with lime, and though it is a leachable species, up to $55 \% \mathrm{Al}$ and $90 \%$ Na recovery were achieved.

Previous attempts of the soda sintering process in Greek bauxite residue achieved the maximum $\mathrm{Al}$ recovery of $76 \%$ [34], may be suggestive that the recovery of aluminum is inhibited greatly through the bulk presence of hematite and aluminum-bearing mineral types existing in the system, which will be followed up in another study. Tathavadkar et al. investigated soda sintering for three different types of bauxite residues from Hungarian, Indian and UK origins [35]. By introducing soda to bauxite residues, accounting for total silica, aluminum and titanate formations during the sintering process at $550-850^{\circ} \mathrm{C}$, they reported a varied recovery of aluminum ranging at a low 55-60\% for MAL (Magyar Alumínium Termelő és Kereskedelmi Zrt.), Hungarian refinery bauxite residue, followed by $83-95 \%$ in ALCAN (Aluminum Company of Canada, Ltd., Toronto, ON, Canada), UK refinery bauxite residue and 77-84\% in INDAL (Indian Aluminium Company, Pathalam, India), Indian refinery bauxite residue [35].

A major difference noted in Hungarian bauxite residue is the higher calcium content $(5.7 \%)$ compared to both ALCAN and INDAL bauxite residue $(<1 \%)$, coinciding with the raised levels of silica. Whittington [36] notes that Ajka's refinery introduces lime addition to the causticization step, where $\mathrm{Ca}(\mathrm{OH})_{2}$ interacts with desilication product (DSP) to form calcium aluminum hydrosilicate or possibly hydrogarnet and calcium aluminum hydrates intermediate which then transforms into calcite and recovered soda. AoG's Greek bauxite residue behavior in the sintering process is more comparable with MAL's Hungarian bauxite residue due to similarities in the existing calcium-bound aluminum bearing minerals i.e., hydrogarnet $\left(\mathrm{Ca}_{3} \mathrm{AlFe}\left(\mathrm{SiO}_{4}\right)(\mathrm{OH})_{8}\right)$ and cancrinite $\left(\mathrm{Na}_{6} \mathrm{Ca}_{2} \mathrm{Al}_{6} \mathrm{Si}_{6}\left(\mathrm{CO}_{3}\right)_{2} \cdot \mathrm{O}_{24} \cdot 2 \mathrm{H}_{2} \mathrm{O}\right)$ [37]. Iron-to-aluminum ratio in INDAL bauxite residue (1.5) is lesser compared to MAL and ALCAN bauxite residues (2.3-2.4), with sodalite phase as desilication product in both INDAL and ALCAN bauxite residues.

Meher and coworkers investigated the effects of divalent alkaline earth metal oxides, such as lime $(\mathrm{CaO})$, barium oxide $(\mathrm{BaO})$ and magnesium oxide $(\mathrm{MgO})$, in soda sintering process using NALCO's bauxite residue from Damanjodi, India [31,32]. The introduction of these alkaline earth metals was designed to capture the free and bound silica in bauxite residue, transforming them to its divalent metal silicate $\left(\mathrm{M}_{2} \mathrm{SiO}_{4}\right.$ or the less thermodynamically stable $\mathrm{MSiO}_{3}$ phase). NALCO's bauxite residue consisted of about $51-57 \% \mathrm{Fe}_{2} \mathrm{O}_{3}, 16-18 \% \mathrm{Al}_{2} \mathrm{O}_{3}$ and $8-12 \% \mathrm{SiO}_{2}$. In Meher et al.'s researches, the addition of metal oxides was performed by weight basis, with 10,15 and $20 \mathrm{~g}$ of either $\mathrm{MgO}, \mathrm{CaO}$ or $\mathrm{BaO}$ added to $100 \mathrm{~g}$ bauxite residue and fixed amount of $\mathrm{Na}_{2} \mathrm{CO}_{3}$ of $25 \mathrm{~g}$. By adding minimal amounts of metal oxide in a soda sinter system, optimized levels of alumina extraction was achieved at $97.64 \%, 98.70 \%$ and $99.50 \%$ using $\mathrm{CaO}, \mathrm{MgO}$ and $\mathrm{BaO}$ respectively [31,32]. Calcium levels in NALCO's bauxite residue were reported below $2.3 \%$ with about $34 \%$ aluminum trapped as muscovite $\mathrm{KAl}_{2}\left(\mathrm{Si}_{3} \mathrm{AlO}_{10}\right)(\mathrm{OH})_{2}$, sillimanite $\mathrm{Al}_{2} \mathrm{SiO}_{5}$, and kaolinite $\mathrm{Al}_{2} \mathrm{Si}_{2} \mathrm{O}_{5}(\mathrm{OH})_{4}$, in bauxite residue, as reported 
by Mohapatra et al. [38]. The rest of aluminum was found in gibbsite, boehmite and alumo-goethite, indicative of the $14 \%$ alumina losses within NALCO's bauxite extraction process [38].

$$
\begin{gathered}
2 \mathrm{MO} / \mathrm{MO}+\mathrm{SiO}_{2} \rightarrow \mathrm{M}_{2} \mathrm{SiO}_{4} / \mathrm{MSiO}_{3} \text { (where } \mathrm{M} \text { represents metals such as } \mathrm{Ba}, \mathrm{Mg}, \mathrm{Ca} \text { ) } \\
\qquad \mathrm{Fe}_{2} \mathrm{O}_{3}+3 \mathrm{C} \rightarrow 2 \mathrm{Fe}+3 \mathrm{CO}
\end{gathered}
$$

The addition of lime, and subsequently exploration of other metal oxides into the sintering process through Meher and coworkers' efforts [31,32,39,40], focuses on capturing the free silica during sintering (Reaction (4)). Adding metallurgical coke into the system, such as Reaction (5), can encourage the recovery of iron downstream by pre-reducing hematite and other iron species. It may also suppress potential unwanted product formation such as complex garnet-type product (e.g., $\left.3(\mathrm{Ca}, \mathrm{Fe}, \mathrm{Mg}) \mathrm{O}(\mathrm{Al}, \mathrm{Fe})_{2} \mathrm{O}_{3} \cdot 3 \mathrm{SiO}_{2}\right)$ that may entrap both iron and aluminum into its matrix.

Figures 1 and 2 reports the Gibbs free energy of formation of different silicate phases and titanate phases at a range of temperature. Silica is more likely to be bonded together with barium or calcium species and predicted to form the more stable species of $\mathrm{Ba}_{3} \mathrm{SiO}_{5}$ or $\mathrm{Ca}_{3} \mathrm{SiO}_{5}$, whereas titania is more likely to form calcium-type bonds such as $\mathrm{Ca}_{3} \mathrm{Ti}_{2} \mathrm{O}_{7}$.

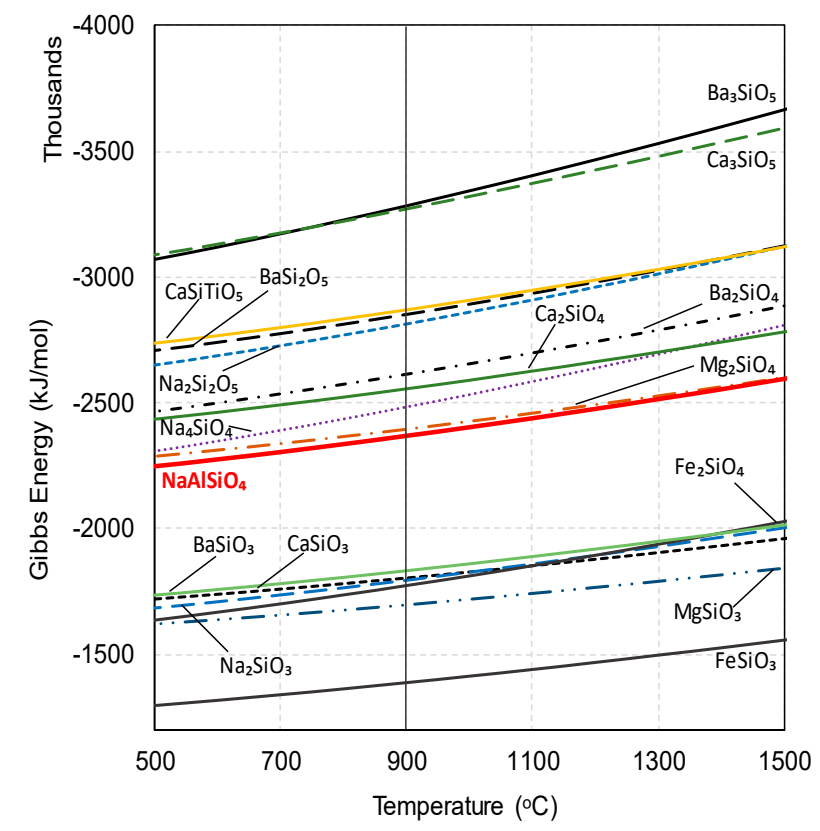

Figure 1. Comparison of Gibbs free energy of phase formation of several silicate species throughout the temperature range by Factsage 7.0 ${ }^{\mathrm{TM}}$ database (Version 7.3, Thermfact/CRCT (Montreal, QC, Canada) and GTT-Technologies (Aachen, Germany)), with silica notably favoring barium presence. 


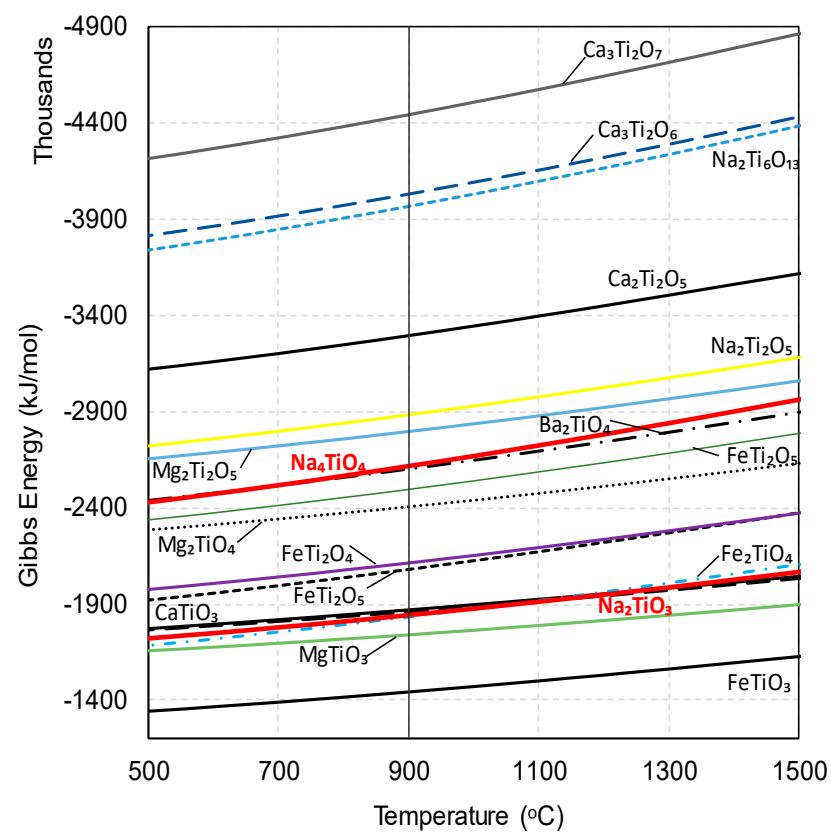

Figure 2. Comparison of Gibbs free energy of phase formation of several titanate species throughout the temperature range by Factsage $7.0^{\mathrm{TM}}$ database, with calcium titanate being most favourable.

\section{Materials and Methods}

\subsection{Characterisation of Bauxite Residue}

Bauxite residue (BR) from Aluminum of Greece's (AoG) high temperature Bayer processing was sampled, homogenised and ground to below $150 \mu \mathrm{m}$. Chemical analysis of the bulk elements in BR is indicated in Table 1. This was performed using the XRF glass disk fusion method with lithium tetraborate in AoG. $1 \mathrm{~g}$ of BR sample is fused as melt in platinum crucible with $1 \mathrm{~g} \mathrm{LiNO}_{3}$ oxidizer, and mixture of flux $(8 \mathrm{~g}$ 83.33\% LiT and $12.82 \% \mathrm{LO}-\mathrm{KBr})$. X-ray diffraction (XRD) and mineralogical analysis was performed using Brucker D6 Focus (XRD, Bruker, Billerica, MA, USA) equipment with integrated EVA software (Version 10.0) for identification of minerals. SEM images were obtained using Jeol6380LV Scanning Electron Microscope (SEM, JEOL, Tokyo, Japan) with INCA software for Energy Dispersive X-Ray Spectroscopy (EDS, EVO MA15 (ZEISS, Oberkochen, Germany) coupled with AZtec X-MAX 80 (Oxford Instruments, Abingdon, UK)) identification. Figure 3 shows the XRD identification of mineralogical phases of AoG's bauxite residue. AoG's high temperature digestion process that uses quick lime to suppress silica levels, indicated similar phase transformations by the identification of hydrogrossular products in the bauxite residue as confirmed by literature. Diaspore, boehmite and gibbsite have been identified as the simple aluminum-bearing minerals, whereas cancrinite and hydrogrossular forms of desilication product are also detected. Chamosite mineral that exists originally from the bauxite ore, reacts slowly in Bayer cycle and remains in bauxite residue [41]. The composition of the Greek bauxite residue is representative of sampling of years 2010 to 2015 with an error margin of $1-10 \%$ for both chemical and mineral assays. Further variations of Greek bauxite residue is explained by Vind et al. that further expresses the trace elements alongside bulk elements in his characterization efforts [41]. 
Table 1. Chemical analysis of AoG bauxite residue.

\begin{tabular}{|c|c|c|c|c|c|c|c|c|c|}
\hline \multirow{2}{*}{ Oxides } & \multicolumn{6}{|c|}{ Major Metals } & \multicolumn{2}{|c|}{ Others } & \multirow{2}{*}{ LOI * } \\
\hline & $\mathrm{Fe}_{2} \mathrm{O}_{3}$ & $\mathrm{Al}_{2} \mathrm{O}_{3}$ & $\mathrm{SiO}_{2}$ & $\mathrm{TiO}_{2}$ & $\mathrm{Na}_{2} \mathrm{O}$ & $\mathrm{CaO}$ & $\mathrm{V}_{2} \mathrm{O}_{5}$ & $\mathrm{SO}_{3}$ & \\
\hline wt $\%$ & 43.51 & 19.26 & 6.50 & 5.49 & 2.81 & 9.59 & 0.17 & 0.47 & 9.40 \\
\hline
\end{tabular}

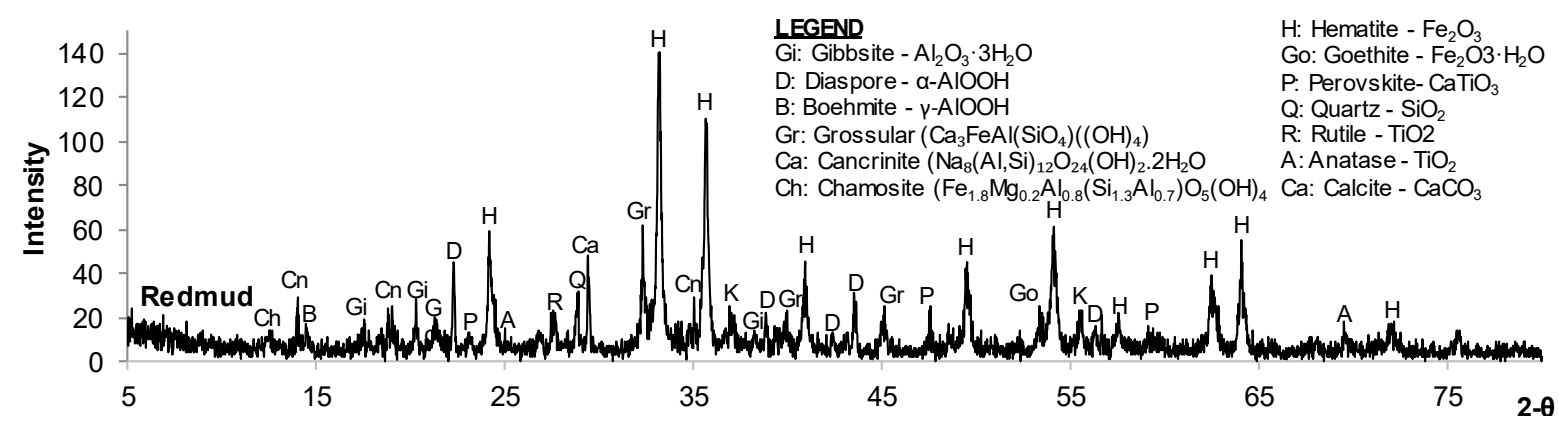

Figure 3. XRD (X-ray diffraction) mineralogical analysis of AoG bauxite residue.

The quantification of phases of AoG bauxite residue is given in Table 2, performed using XDB software designed by Sajó that uses a full-profile fit method that fits measured spectra to a simulated composite of mineral standards contained in the database [42]. This result was also verified in another study [43], where where minerals were quantified in different stages of soda sintering and leaching process. The mineral phases shown in Table 2 were utilized for the prediction of phases in sinter products by using the thermodynamic software Factsage $7.0^{\mathrm{TM}}$. However, the simplification of complex minerals with simpler ones existing in the software database was necessary.

Table 2. XRD Mineralogical Quantification using XDB Software by Sajo [42,43].

\begin{tabular}{ccccccccccccc}
\hline $\begin{array}{c}\text { Miner } \\
\text { alogy }\end{array}$ & $\begin{array}{c}\text { Anat } \\
\text { ase }\end{array}$ & $\begin{array}{c}\text { Boeh } \\
\text { mite }\end{array}$ & $\begin{array}{c}\text { Gibb } \\
\text { site }\end{array}$ & $\begin{array}{c}\text { Hema } \\
\text { tite }\end{array}$ & $\begin{array}{c}\text { Goet } \\
\text { hite }\end{array}$ & $\begin{array}{c}\text { Perovs } \\
\text { kite }\end{array}$ & $\begin{array}{c}\text { Cancri } \\
\text { nite }\end{array}$ & $\begin{array}{c}\text { Dias } \\
\text { pore }\end{array}$ & $\begin{array}{c}\text { Cal } \\
\text { cite }\end{array}$ & $\begin{array}{c}\text { Rut } \\
\text { ile }\end{array}$ & $\begin{array}{c}\text { Gross } \\
\text { ular }\end{array}$ & $\begin{array}{c}\text { Chamo } \\
\text { site }\end{array}$ \\
\hline $\begin{array}{c}\text { Phase } \\
\text { percentage } \\
\%\end{array}$ & 1.0 & 2.1 & 1.0 & 37.5 & 5.2 & 5.2 & 11.5 & 13.0 & 4.2 & 0.5 & 14.6 & 2.1 \\
\hline
\end{tabular}

\subsection{Laboratorial Methods in Sintering Optimisation}

Figure 4 indicates the procedure of sintering and leaching in this lab-scale study. Lab-grade reagents of $\mathrm{Na}_{2} \mathrm{CO}_{3}$ (99.8\%, Chembiotin), $\mathrm{CaO}$ (>98\%, Merck), $\mathrm{BaO}$ (99.5\%, Alfa Aesar), $\mathrm{MgO}$ (>98\%, Sigma Aldrich) and metallurgical coke $(80.3 \% \mathrm{C})$ were used as reactive additives to the bauxite residue in this study. Dried homogenised bauxite residue $(<150 \mu \mathrm{m})$ were mixed together with the additives and placed into alumina crucibles. For the lab-scaled experiments, the muffle furnace $\left(T_{\max }: 1700{ }^{\circ} \mathrm{C}\right)$ shown in Figure 5 is as below. 


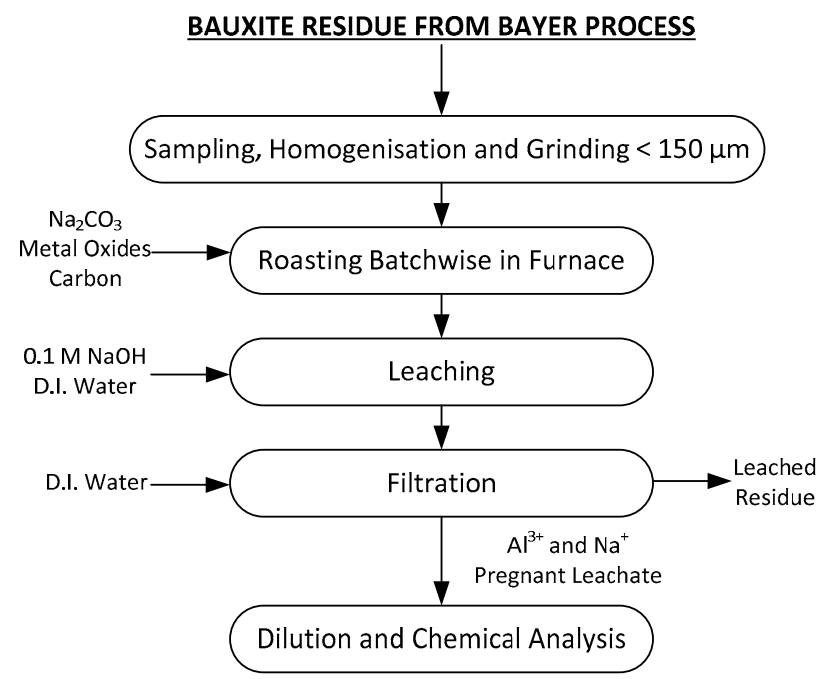

Figure 4. Procedure for sintering of AoG's Greek bauxite residue.

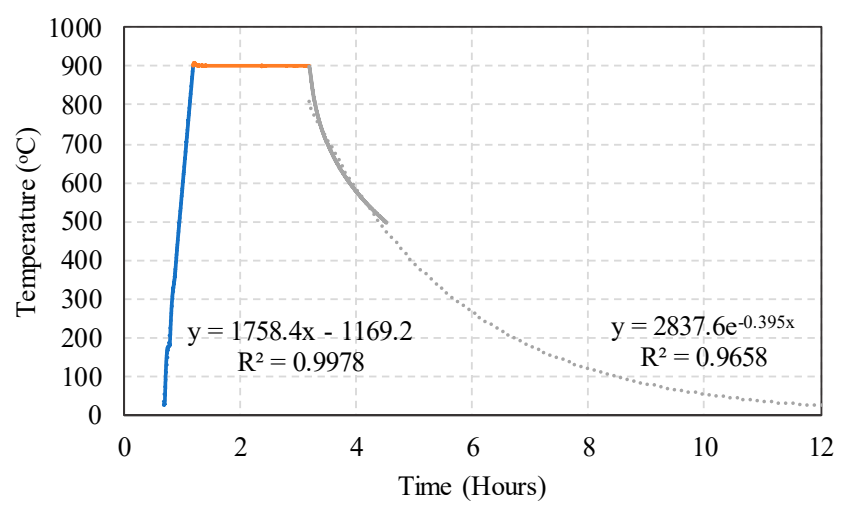

Figure 5. Temperature heating profile of muffle furnace.

The heating rate was kept to $30-35^{\circ} \mathrm{C}$ per min, and after sintering within set holding time, indicated in the plateau region of temperature profile in Figure 5, was then left to cool overnight. The cooling kinetics were out of the scope of this study. Introduction of inert atmosphere for carbon-reduction aided sintering process with $5 \mathrm{~N} \mathrm{~L} / \mathrm{min}$ argon flow rate, where stoichiometric to $50 \%$ excess carbon required to reduce iron were used. Current leaching conditions during sintering optimization were kept at $80^{\circ} \mathrm{C}$ for $4 \mathrm{~h}$, at $240 \mathrm{rpm}$ stirring rate, solid-to-liquid ratio of $1.5 \mathrm{~g} / 100 \mathrm{~mL}(1: 66)$ in $0.1 \mathrm{M} \mathrm{NaOH}$ solution. Leachates were then filtered, diluted and sent to Atomic Absorption Spectroscopy (AAS, Waltham, MA, USA) for chemical analysis of aluminum and silica. Leached residue was collected and sent for XRF (Perform'X, Thermo Fisher Scientific ${ }^{\mathrm{TM}}$, Waltham, MA, USA) analysis, with mass balance of filtered solids accounted for sodium analysis to reduce experimental error and interference during AAS analysis when leached in $0.1 \mathrm{M} \mathrm{NaOH}$. Two experimental series were performed. In the first the soda sintering process was studied in the presence of $50 \%$ excess of soda over stoichiometric amount required for sodium aluminate conversion and in the absence of any additives. In the second the effect of additives was studied. Particularly, AoG's bauxite residue was subjected to $20 \mathrm{~g}$ of additives (divalent metal oxides) to $100 \mathrm{~g}$ of bauxite residue, with $25 \mathrm{~g}$ of $\mathrm{Na}_{2} \mathrm{CO}_{3}(\sim 50 \%$ excess soda amounts required to form $\mathrm{NaAlO}_{2}$ ). 


\section{Results and Discussion}

\subsection{Effect of Sintering Temperature and Retention Time on Metals Recoveries}

Figure 6 shows the thermodynamic predictions of solid phase's evolution during sintering temperature increase. For performing this thermodynamic analysis, the real desilication phases existing in AoG's Bauxite residue (namely, cancrinite, sodalite and hydrogrossular) were replaced by ones (such as Ferrocordierite, Grossularite and Albite) which was available in the Factsage $7.0^{\mathrm{TM}}$ software.

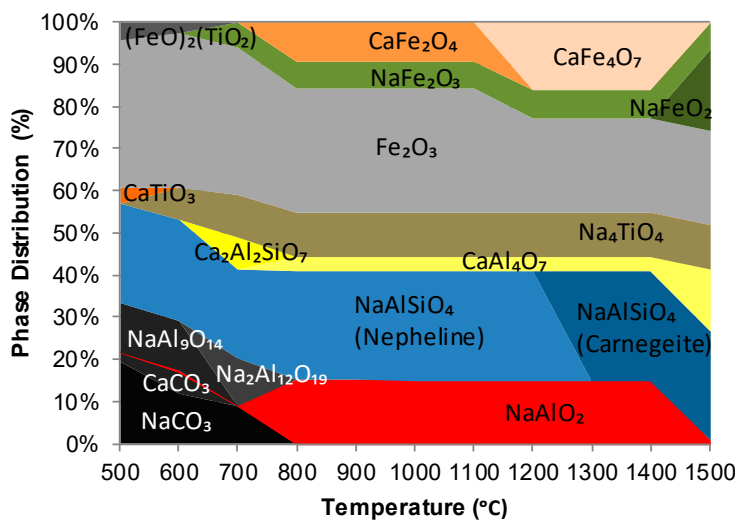

(a)

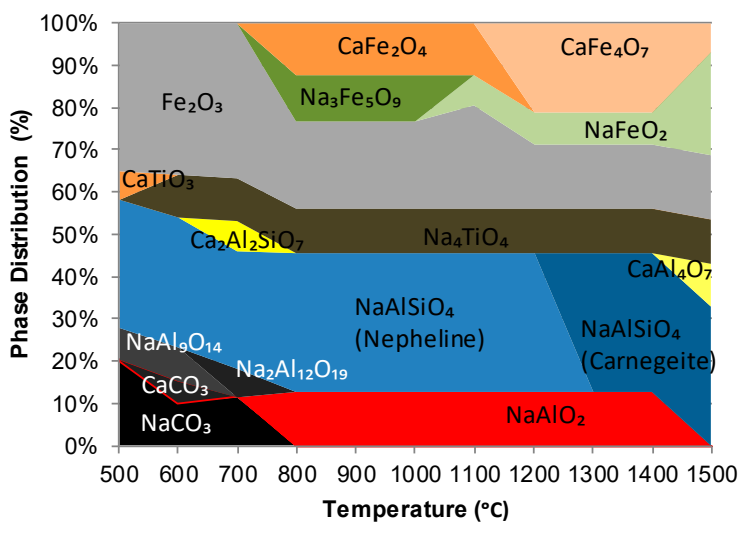

(c)

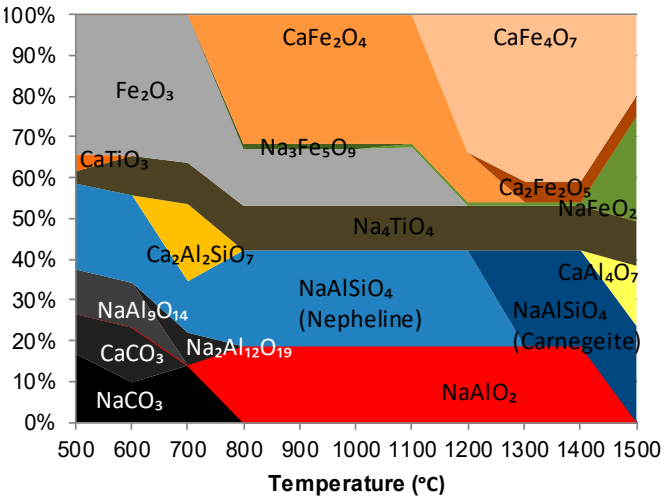

(b)

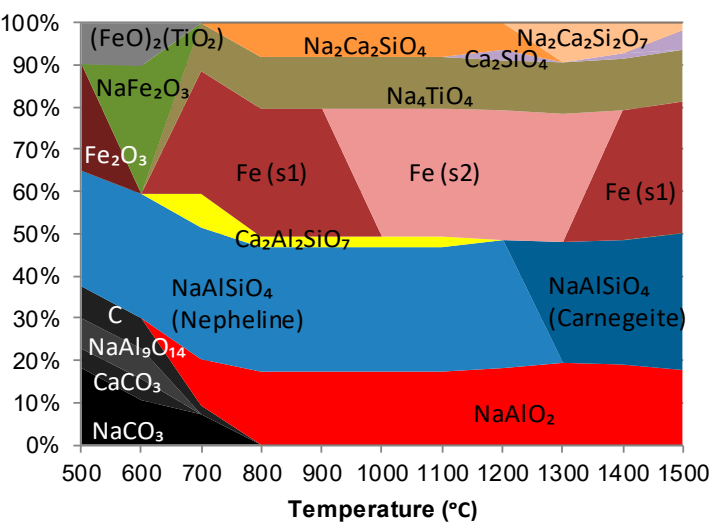

(d)

Figure 6. Thermodynamic predictions of sinter phase formations with different representatives of desilication product such as (a) Ferrocordierite, $\mathrm{Fe}_{2} \mathrm{Al}_{4} \mathrm{Si}_{5} \mathrm{O}_{18}$ (b) Glossularite, $\mathrm{Ca}_{3} \mathrm{Al}_{2} \mathrm{Si}_{3} \mathrm{O}_{12}$ (c) Albite, $\mathrm{NaAlSi}_{3} \mathrm{O}_{8}$ (d) Albite, $\mathrm{NaAlSi}_{3} \mathrm{O}_{8}$ with $50 \%$ excess of soda over stoichiometric amount.

As seen in Figure 6, at 50\% stoichiometric excess of soda in sintering system achieves only partial conversion into sodium aluminate species, and sodium aluminosilicate forms of nepheline and carnegeite were still present in the system. $\mathrm{NaAl}_{9} \mathrm{O}_{14}$ and $\mathrm{Na}_{2} \mathrm{Al}_{12} \mathrm{O}_{19}$ represented unreacted $\beta$-alumina and $\beta^{\prime \prime}$-alumina phases respectively. Silica presence was predicted to be a constraint for the total transformation of aluminum bearing phases to leachable sodium aluminate which is in agreement with previous studies on soda sintering at high temperatures [12]. It is interesting to note that despite glossularite's high calcium content when replaced as a desilication product, the result of the predictive transformation was still the same. The calcium showed an affinity towards iron, with calcium ferritic sinter products $\left(\mathrm{CaFe}_{2} \mathrm{O}_{4}, \mathrm{CaFe}_{4} \mathrm{O}_{7}\right.$ and $\left.\mathrm{Ca}_{2} \mathrm{Fe}_{2} \mathrm{O}_{5}\right)$ formed instead of binding towards the available silica. This agrees with Hodge et al., noting that calcium has the tendency to preferentially react with iron phases instead of silica during bauxite residue soda sintering process [43]. In Figure 6d, albite 
was used as the extrapolative value of desilication product, and the addition of carbon as reducing agent promoted iron reduction and was predicted to suppress the calcium-iron interaction, though it presents only a slight increase of sodium aluminate phase over nepheline/carnegeite species.

Figure $7 \mathrm{a}$ shows the metal recoveries as a function of sintering temperature at $2 \mathrm{~h}$ retention time and $5 \%$ stoichiometric excess of soda in bauxite residue. At $900{ }^{\circ} \mathrm{C}$ it reaches at $55 \%$ due to entrapment of part of aluminum in sodium aluminosilicate and calcium aluminosilicate species which are by definition very difficult soluble in diluted $\mathrm{NaOH}$ solutions. This conclusion is supported by the behaviour of silica which was recovered at a value lower than $20 \%$ showing that the dissolution of silicate phases formed during sintering is limited in diluted $\mathrm{NaOH}$ solutions hindering the alumina recovery. In Figure $7 \mathrm{~b}$, once excess soda levels were investigated and 50\% stoichiometric excess of soda in bauxite residue was used, it was noted that increased retention time of sintering from 2 to $4 \mathrm{~h}$ displayed very slight change towards recovery. Aluminum recovery agrees with the thermodynamic predictions.

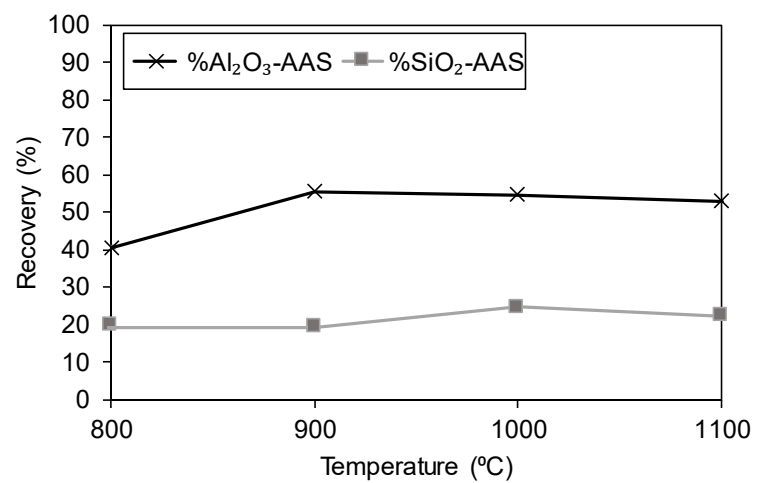

(a)

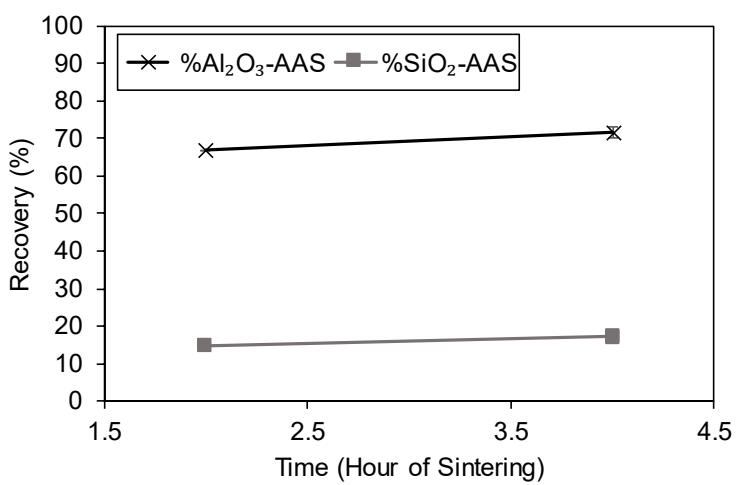

(b)

Figure 7. Recovery of $\mathrm{Al}_{2} \mathrm{O}_{3}$ and $\mathrm{SiO}_{2}$ for (a) temperature-variable sintering experiments with $5 \%$ stoichiometric excess of $\mathrm{Na}_{2} \mathrm{CO}_{3}$, and (b) time-variable with $50 \%$ stoichiometric excess of $\mathrm{Na}_{2} \mathrm{CO}_{3}$.

\subsection{Effect of $\mathrm{Na}_{2} \mathrm{CO}_{3}$ Excess on Metals Recoveries}

Figure 8 a shows the thermodynamic predictions of sinter phase formation when soda $\left(\mathrm{Na}_{2} \mathrm{CO}_{3}\right)$ is added in excess to stoichiometric amounts. The solid sinter phase distribution of sodium aluminate when soda is introduced in excess is noted reach a plateau of equilibrium with nepheline phase when the soda excess is equal or greater than $200 \%$. The metastable states of $\mathrm{Na}_{2} \mathrm{Ca}_{3} \mathrm{Al}_{16} \mathrm{O}_{28}$ and $\mathrm{Na}_{2} \mathrm{Ca}_{8} \mathrm{Al}_{6} \mathrm{O}_{18}$ were suppressed and excluded from the thermodynamic prediction in the software. The calcium content was observed to partially form calcium aluminate and change into sodium calcium silicate instead of beginning at $100 \%$ excess. Hematite is predicted to initially bind preferentially towards calcium and then shift to sodium instead, forming potential soluble sodium ferrite phases. Actual experimental results further confirmed the linear increase until reaching plateau, albeit at an earlier range with levels of $67-70 \%$ being reached when $50 \%$ excess of stoichiometric soda required was added. 


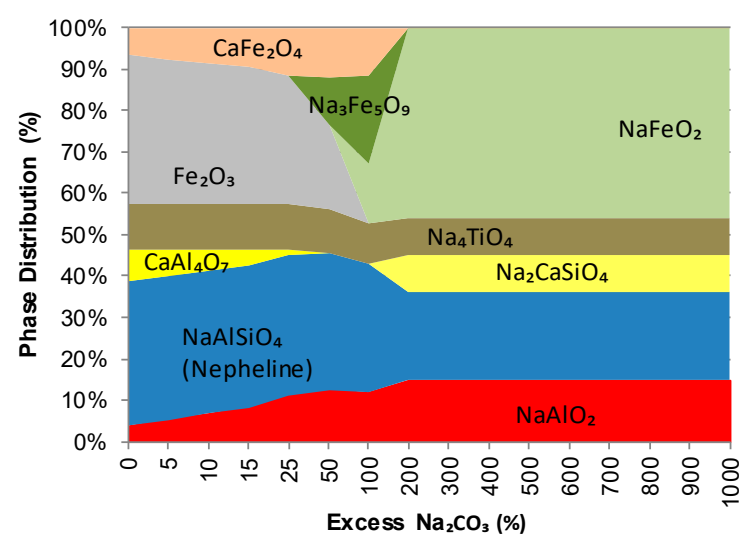

(a)

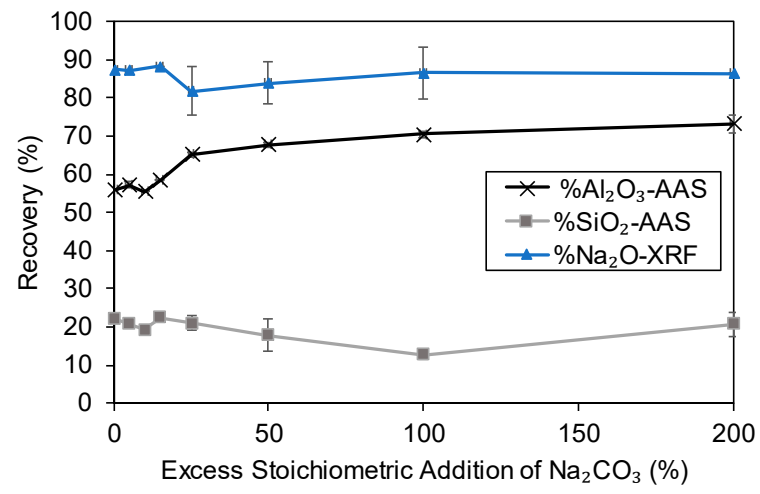

(b)

Figure 8. (a) Thermodynamic predictions of sinter phase formation and (b) results of experimental recovery of $\mathrm{Al}_{2} \mathrm{O}_{3}, \mathrm{SiO}_{2}$, and $\mathrm{Na}_{2} \mathrm{O}$ at the range of excesses of stoichiometric $\mathrm{Na}_{2} \mathrm{CO}_{3}$ additions at $900{ }^{\circ} \mathrm{C}$ for $2 \mathrm{~h}$.

Figure 9 shows the XRD mineral identification of sinters and leached residue at 50\% excess soda addition. Sodium aluminum silicate $\left(\mathrm{NaAlSiO}_{4}\right)$ observations in leached residue and sinters confirmed that the nepheline-sodium aluminate equilibrium does exist. The consumption of soda reagent into iron products such as sodium iron titanium oxide $\left(\mathrm{NaFeTiO}_{4}\right)$ and calcium products such as harmunite $\left(\mathrm{CaFe}_{2} \mathrm{O}_{4}\right)$ which were the unwanted side reactions further fortifies the existence of nepheline-sodium aluminate equilibrium despite soda excess levels during sintering, though several overlapping peaks of both species lean to a larger confirmed harmunite presence with peaks from 40-48 degrees. Though silica is observed to be within the range of $10-20 \%$, silica dissolution is still observed in the leaching system. Sodium recovery at $80 \%$ to $90 \%$ range throughout the experimental data indicates that a variety of sodium-soluble products exists.

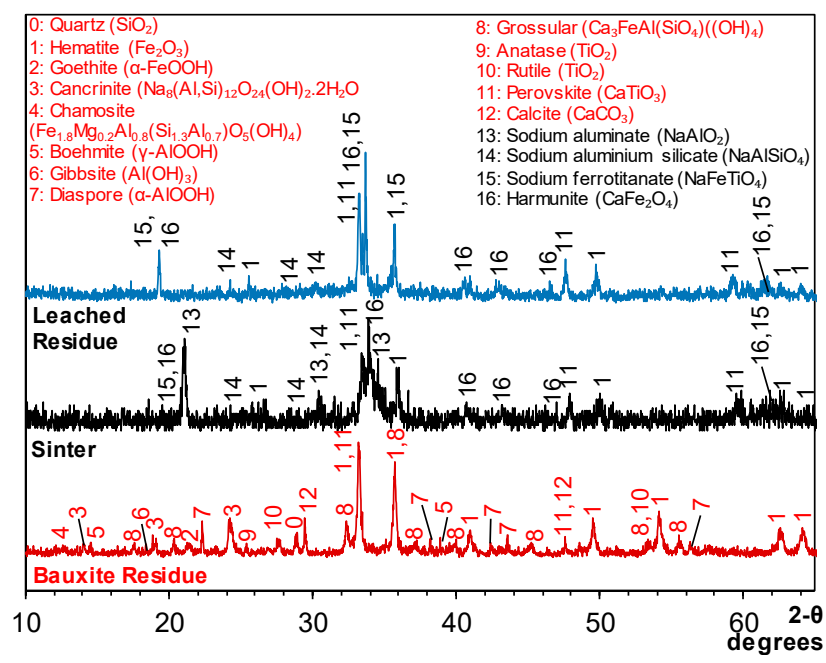

Figure 9. XRD of mineralogical phases for $50 \%$ stoichiometric excess $\mathrm{Na}_{2} \mathrm{CO}_{3}$ at $900{ }^{\circ} \mathrm{C}$ and for $2 \mathrm{~h}$.

Red font: Existing minerals in bauxite residue; black font: Transformed sinter and leached minerals.

\subsection{Effect of Carbon Additions on Metals Recoveries}

After fixing to $50 \%$ excess of soda which reduces the amount of soda required per aluminum recovery, the study next focused on the suppression of side reactions through the reduction of iron with metallurgical coke additions as a carbon source in inert conditions. The thermodynamic prediction of sinter phases in Figure 10a indicates that the equilibrium that exists between leachable 
sodium aluminate and nepheline form still exists despite the conversion of hematite or goethite into metallic iron.

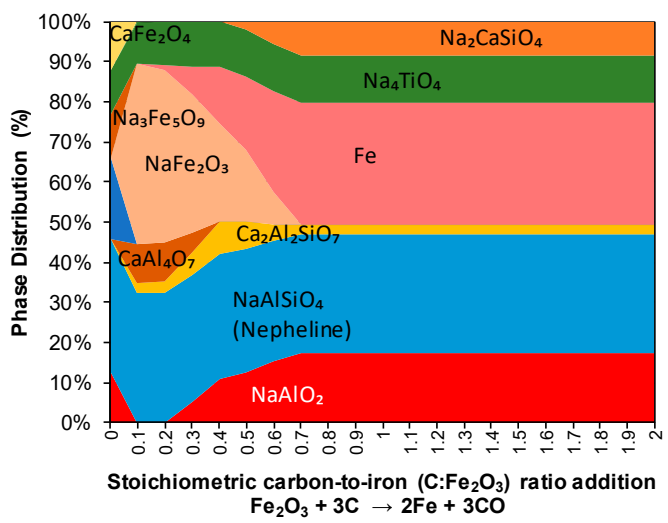

(a)

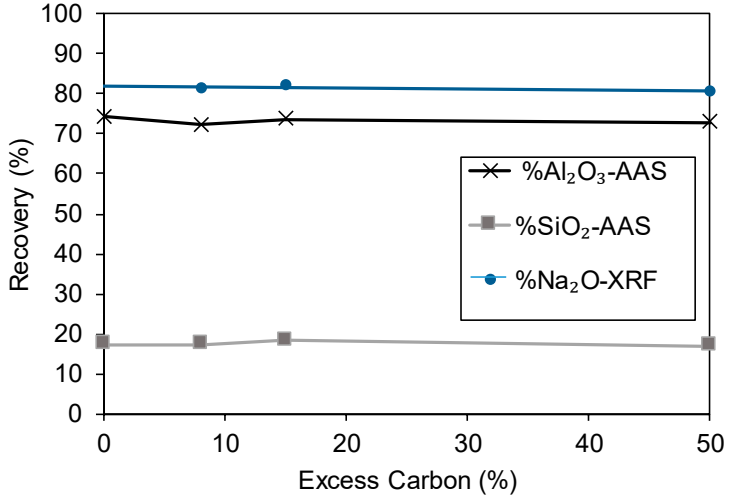

(b)

Figure 10. (a) Thermodynamic predictions of sinter phase formation and (b) results of experimental recovery of $\mathrm{Al}_{2} \mathrm{O}_{3}, \mathrm{SiO}_{2}$, and $\mathrm{Na}_{2} \mathrm{O}$ at the range of excesses of stoichiometric carbon additions (based on Carbon: $\mathrm{Fe}_{2} \mathrm{O}_{3}$ ratio from bauxite residue) with $50 \%$ excess soda, $900{ }^{\circ} \mathrm{C}$ for $2 \mathrm{~h}$.

Figure 11 shows the XRD confirmations of mineral phases present in the sinter product and leached residue. Part of the iron formed sodium iron oxide while hematite was partially reduced to magnetite and wustite. Though the calcium iron oxide species were now suppressed, as it can be seen from Figure 10a thermodynamic predictions, there was a secondary issue of gehlenite $\left(\mathrm{Ca}_{2} \mathrm{Al}_{2} \mathrm{SiO}_{7}\right)$ formation on top of nepheline throughout the range of stoichiometric carbon additions, causing additional aluminum losses downstream.

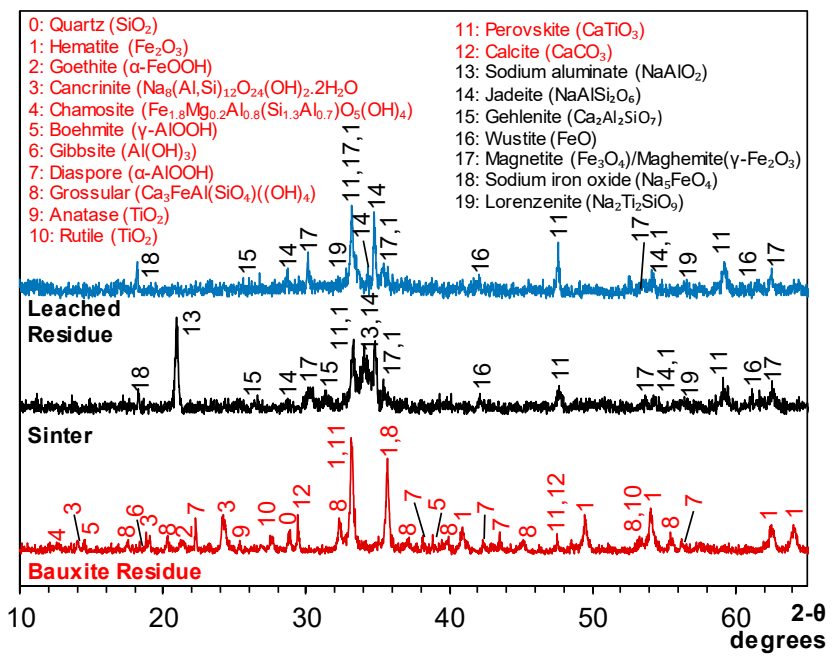

Figure 11. XRD of mineralogical phases for stoichiometric carbon addition needed to produce Fe from Reaction (5), with $50 \%$ stoichiometric excess $\mathrm{Na}_{2} \mathrm{CO}_{3}$ at inert conditions at $900{ }^{\circ} \mathrm{C}$ and for $2 \mathrm{~h}$. Red font: Existing minerals in bauxite residue; black font: Transformed sinter and leached minerals.

Figure 1 shows the mineralogy of sinter and leached residue, confirming the theoretical formations of sodium aluminum silicates and gehlenite, though latter phases were minor. The suppression of soluble sodium-iron products occurs past 0.7 stoichiometric ratio indicated that carbon addition is favorable at stoichiometric ratio onwards. This was also confirmed in the experimental results in Figure $10 \mathrm{~b}$, and an increase from $68 \%$ to $75 \%$ is observed in aluminum recovery, though sodium recovery 
reduces to 3\% lesser amount that the previous soda excess additions in atmospheric environment. Silica amount remains relatively unchanged within the range of $18 \%$ recovery.

\subsection{Effect of $\mathrm{CaO}$ Additions on Phase Transformations during Sintering Process}

Following soda and carbon additions, the addition of lime into the sintering process of $20 \mathrm{~g} \mathrm{CaO}$ to $100 \mathrm{~g}$ bauxite residue ( $80 \%$ excess to stoichiometric requirements to form $\mathrm{Ca}_{2} \mathrm{SiO}_{4}$ ) is necessary to investigate the consumption of free and bound silica in desilication products, relying on higher thermodynamic affinity with calcium. Figure 12 shows the thermodynamic predictions of sinter phases at excess lime additions. The thermodynamic predictions made by Factsage 7.0 ${ }^{\mathrm{TM}}$, however, shows that calcium indeed reacts with iron to form $\mathrm{CaFe}_{2} \mathrm{O}_{4}$ and $\mathrm{Ca}_{2} \mathrm{Fe}_{2} \mathrm{O}_{5}$, when iron is available in atmospheric conditions at $900{ }^{\circ} \mathrm{C}$.

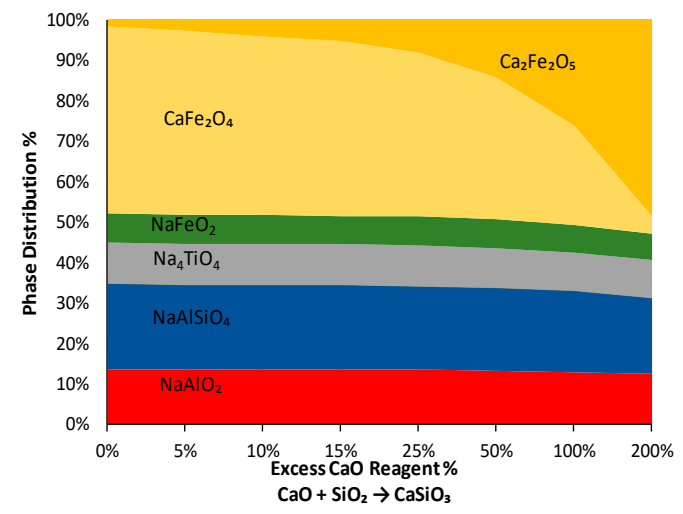

(a)

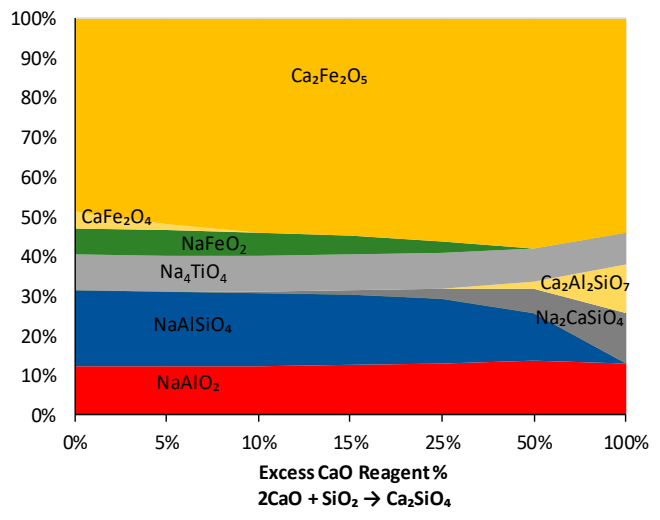

(b)

Figure 12. Thermodynamic predictions of sinter phase formation (a) when monocalcium silicate is expected or (b) when dicalcium silicate is expected, at excess of lime additions at $50 \%$ excess soda, $900{ }^{\circ} \mathrm{C}$ for $2 \mathrm{~h}$.

Compared to Figure 8a, thermodynamics of soda only addition into the sinter of bauxite residue notes that sodium preferably reacts to form nepheline species and sodium titanate species at lower than $50 \%$ soda excess levels, whereas, calcium is bound to either aluminum or iron initially. At between $50 \%$ and $200 \%$ soda excess levels, sodium ferrite species of intermediate $\mathrm{Na}_{3} \mathrm{Fe}_{5} \mathrm{O}_{9}$ forms, transforming into $\mathrm{NaFeO}_{2}$ at even higher soda concentrations. Sodium ferrite then dissolves back as sodium, hence phases do not inhibit system. Also at higher soda levels (Figure 8a), soda and calcium is predicted to preferentially react, still existing in equilibrium with nepheline species. In Figure 12, the excess $\mathrm{CaO}$ predicted to be added in the sintering system is divided into two amounts, Figure 12a, one that encourages monocalcium silicate formation and the other, Figure $12 b$, dicalcium silicate instead. Increased additions of lime only encourage calcium to complex into $\mathrm{Ca}_{2} \mathrm{Fe}_{2} \mathrm{O}_{5}$ stable species instead, with nepheline phase still existing in equilibrium amounts to sodium aluminate species. Grossular species in the form of $\mathrm{Ca}_{2} \mathrm{Al}_{2} \mathrm{SiO}_{7}$ and sodium calcium silicate species $\left(\mathrm{Na}_{2} \mathrm{CaSiO}_{4}\right)$ exists when $\mathrm{CaO}$ is added in excess.

Figure 13 shows the XRD identification of the sinter phase and leached residue, whereas Figure 14 shows the SEM confirmations of minerals identified in the sinters and leached residue. The sinters confirmed the presence of sodium aluminate, calcium ferrite and titanate peaks as well as dicalcium silicate in both XRD and SEM. In Figure 13, both presence of harmunite $\left(\mathrm{CaFe}_{2} \mathrm{O}_{4}\right)$ and srebrodolskite $\left(\mathrm{Ca}_{2} \mathrm{Fe}_{2} \mathrm{O}_{5}\right)$ were detected, where angular rods exist in both sinters and leached residue images in SEM (Figure 14, (2) and (6), nano-rods, SEM empirical formula of $\mathrm{CaFe}_{6.9} \mathrm{O}_{10}$ ). Iron was found to be entrained at varying levels throughout SEM-EDS element identification. 


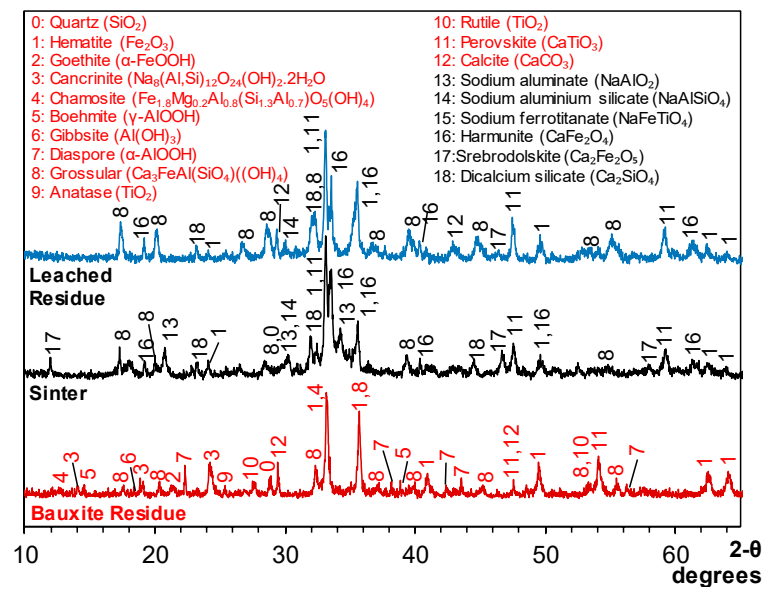

Figure 13. $\mathrm{XRD}$ of mineralogical phases for lime additions $(20 \mathrm{~g} \mathrm{CaO} / 100 \mathrm{~g}$ bauxite residue, equivalent to $80 \%$ excess $\mathrm{CaO}$ addition for $\mathrm{Ca}_{2} \mathrm{SiO}_{4}$ formation), and $50 \%$ excess soda at $900{ }^{\circ} \mathrm{C}$ and for $2 \mathrm{~h}$. Red font: Existing minerals in bauxite residue; black font: Transformed sinter and leached minerals.

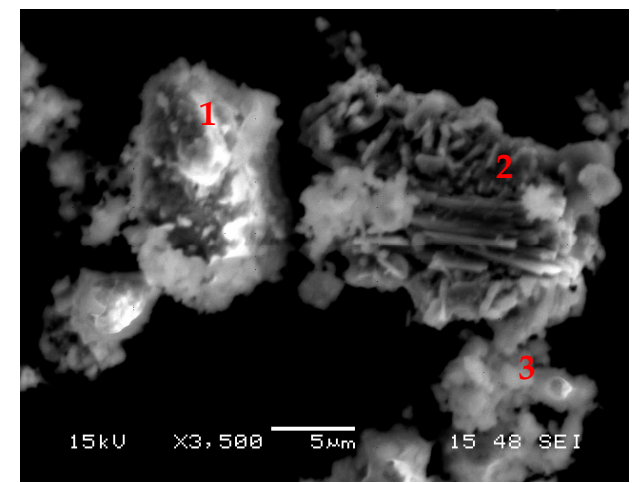

(a)

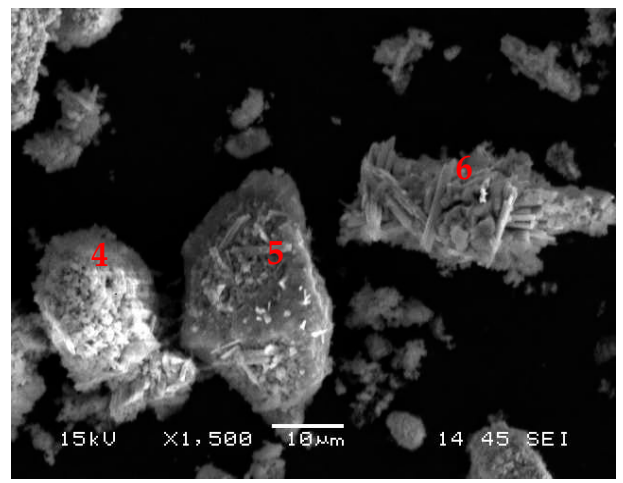

(b)

Figure 14. SEM (scanning electron microscope) mineral identifications in $\mathrm{CaO}, \mathrm{Na}_{2} \mathrm{CO}_{3}$ and bauxite residue (a) Sinter product; (1) Sodium aluminate, (2) Calcium ferrite, Calcium titanate, (3) Calcium silicate, sodium calcium silicate; and (b) Leached residue; (4) Calcium ferrite, calcium silicate, (5) Calcium ferrite, grossular product, (6) Calcium ferrite (more details in Supplementary Materials).

Calcium sodium aluminum silicate (grossular, SEM empirical formula of $\mathrm{Ca}_{2.23} \mathrm{Na}_{1.11} \mathrm{AlSi}_{1.15} \mathrm{FeO}_{9.6}$ ) trace remainder in both XRD and SEM images (Figure 14, (5)) confirms the thermodynamic inhibition of aluminum phase that converts from nepheline/sodium aluminum silicate phases towards grossular products instead of sodium aluminate phases, indicating incomplete recovery of aluminum. Meher et al. [31,44] also detected similar formations of minerals in lime/calcite added soda sinter system, with calcium aluminum silicate detected instead of sodium aluminum silicate type products, though alumina extraction was more favourable at $10 \mathrm{~g} \mathrm{CaO}$ ratio at $900{ }^{\circ} \mathrm{C}$ [44]. Kirschsteinite $\left(\mathrm{CaFeSiO}_{4}\right)$ was also detected in their paper [44] and it may exist in minimal amounts that remained undetected in our sinter system.

\subsection{Effect of $\mathrm{MgO}$ Additions on Phase Transformation during Sintering Process}

Figure 15 shows the thermodynamic prediction of the effects of $\mathrm{MgO}$ added in excess of stoichiometric amounts to form magnesium silicate product. 


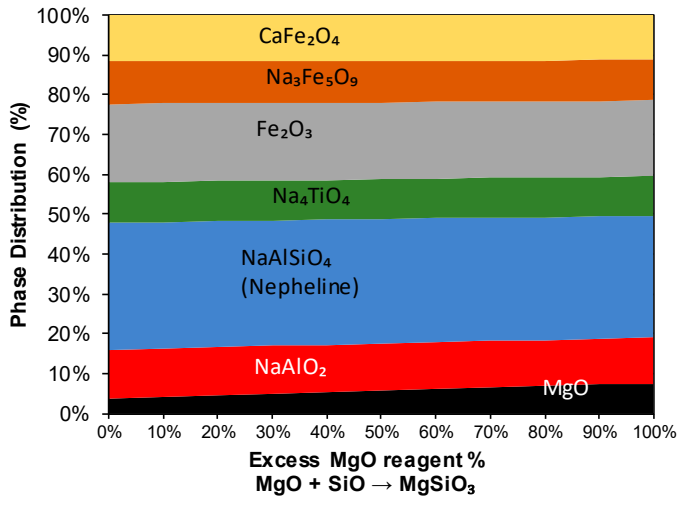

(a)

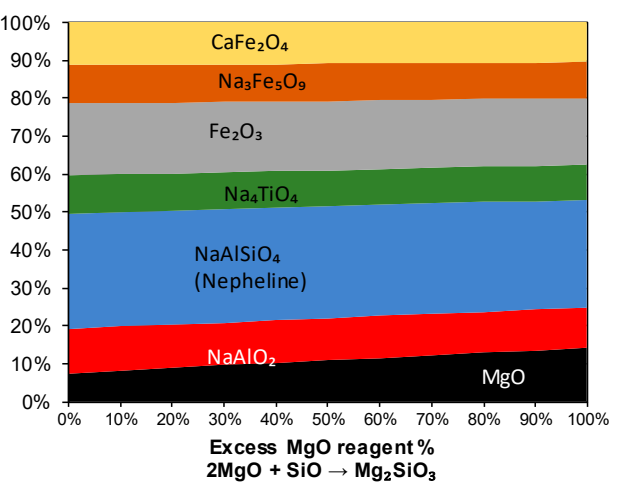

(b)

Figure 15. Thermodynamic predictions of sinter phase formation (a) when monomagnesium silicate is expected or (b) when dimagnesium silicate is expected at excess of $\mathrm{MgO}$ additions at $50 \%$ excess soda, $900{ }^{\circ} \mathrm{C}$ for $2 \mathrm{~h}$.

Figures 16 and 17 shows the XRD identification and SEM confirmations of minerals identified in the sinters and leached residue respectively. The effect of the addition of magnesium oxide in the soda sintering system of $20 \mathrm{~g} \mathrm{MgO}$ to $100 \mathrm{~g}$ bauxite residue (130\% excess to stoichiometric requirements to form $\mathrm{Mg}_{2} \mathrm{SiO}_{4}$ ) when thermodynamically interpreted, is limited and not able to push the nepheline product reaction towards sodium aluminate. Any calcium existing in the system is said to change into $\mathrm{CaFe}_{2} \mathrm{O}_{4}$ product in Figure 15, and sodium reacts with iron and titanium to form $\mathrm{Na}_{3} \mathrm{Fe}_{5} \mathrm{O}_{9}$ and $\mathrm{Na}_{4} \mathrm{TiO}_{4}$ preferentially.

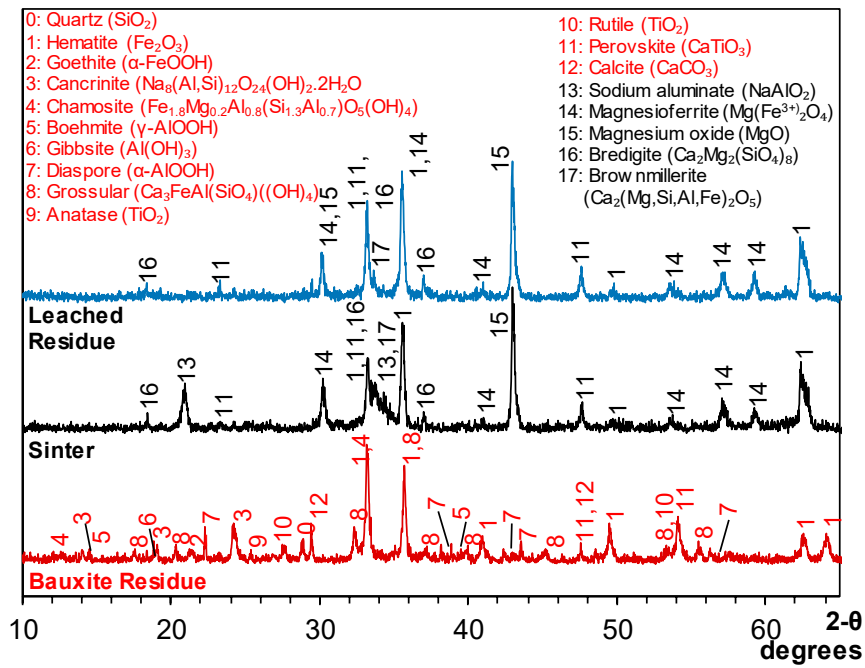

Figure 16. $\mathrm{XRD}$ of mineralogical phases for $\mathrm{MgO}$ additions (20 g MgO/100 $\mathrm{g}$ bauxite residue) at atmospheric conditions at $900{ }^{\circ} \mathrm{C}$ and for $2 \mathrm{~h}$. Red font: Existing minerals in bauxite residue; black font: Transformed sinter and leached minerals. 


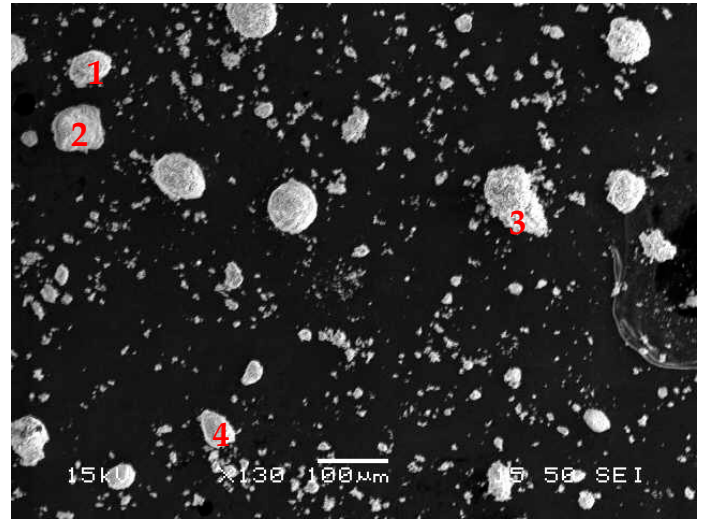

(a)

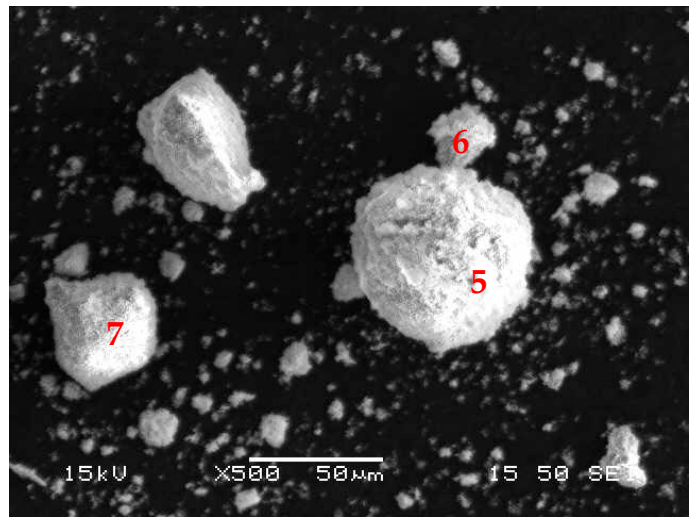

(b)

Figure 17. SEM mineral identifications in $\mathrm{MgO}, \mathrm{Na}_{2} \mathrm{CO}_{3}$ and bauxite residue (a) sinter products; (1) Calcium iron aluminum sodium oxide, (2) Magnesium oxide, (3) Calcium magnesium iron aluminum sodium oxide (4) Magnesium iron oxide, Calcium titanate, Calcium magnesium silicate, and (b) Leached residue; (5) Magnesium oxide coating, (6) Calcium magnesium iron oxide (7) Calcium magnesium iron aluminum sodium oxide (more details in Supplementary Materials).

This contrasts with the XRD of experimental results of $20 \mathrm{~g} \mathrm{MgO}$ additions in $100 \mathrm{~g}$ bauxite residue in Figure 16, where complex sinter mineral formations such as magnesioferrite $\left(\mathrm{Mg}\left(\mathrm{Fe}^{3+}\right)_{2} \mathrm{O}_{4}\right)$, bredigite $\left.\left(\mathrm{Ca}_{2} \mathrm{Mg}_{2} \mathrm{SiO}_{4}\right)_{8}\right)$ and brownmillerite $\left(\mathrm{Ca}_{2}(\mathrm{Mg}, \mathrm{Al}, \mathrm{Fe})_{2} \mathrm{O}_{5}\right)$ were detected in addition to unreacted magnesia. Leached residue indicates that excess $\mathrm{MgO}$ as well as these complex phases remains as part of the leftover residue and that aluminum remains trapped still from the conversion towards these complexes.

SEM mineral identifications in Figure 17 confirms a series of complex compound containing calcium iron aluminum sodium oxide and calcium magnesium iron aluminum sodium oxide (SEM empirical formulas of $\mathrm{CaFe}_{2.4} \mathrm{AlNa}_{1.6} \mathrm{O}_{9}$ and $\mathrm{CaFe}_{4.5} \mathrm{Mg}_{7} \mathrm{Al}_{1.2} \mathrm{Na}_{1.6} \mathrm{O}_{13}$ ). Complex sinter area that contains calcium magnesium iron aluminum and silicon (Total SEM empirical formula of $\left.\mathrm{Ca}_{1.8} \mathrm{Fe}_{11.6} \mathrm{SiTi}_{1.48} \mathrm{Mg}_{6.7} \mathrm{Al}_{2.6} \mathrm{O}_{44.7}\right)$ indicates that the sinter product becomes a heterogenous mix of elements that are harder to distinguish from topographical SEM-EDS method. In Figure 16, they appear as bredigite and brownmillerite species instead.

A combination of calcium magnesium iron oxide (SEM empirical formula of $\mathrm{CaMg}_{8.9} \mathrm{Fe}_{11} \mathrm{O}_{16}$ ) contains minute traces of distributed calcium, and empirical formula indicates that particles such as Figure 17 (6) suggests that magnesioferrite species are present in the system, with partial calcium substitution in the species. Overall, adding $\mathrm{MgO}$ does not aid the sinter reactions as they still contain unfavourable complex garnet-type products. Meher and Padhi reports cancrinite and bayerite mineral identifications in their XRDs of $\mathrm{MgO}$ and $\mathrm{Na}_{2} \mathrm{CO}_{3}$ sintered bauxite residue system, though magnesium was found to be bound with ferrite, titanate and silica forms [40].

\subsection{Effect of $\mathrm{BaO}$ Additions on Phase Transformations during Sintering Process}

By introducing barium oxide into the soda sinter system, the thermodynamic prediction of minerals changes to improve the recovery of aluminum via sodium aluminate phases. Figure 18 shows that in the thermodynamic predictions, barium favourably reacts towards the available silica and preferentially binds them into either $\mathrm{Ba}_{2} \mathrm{Ca}_{2} \mathrm{Si}_{4} \mathrm{O}_{16}$ or $\mathrm{Ba}_{2} \mathrm{SiO}_{4}$ forms, pushing also the equilibrium of reaction from sodium aluminum silicate product towards sodium aluminate product, especially when added in excess of $100 \%$ stoichiometric requirements for $\mathrm{Ba}_{2} \mathrm{SiO}_{4}$ formation. 


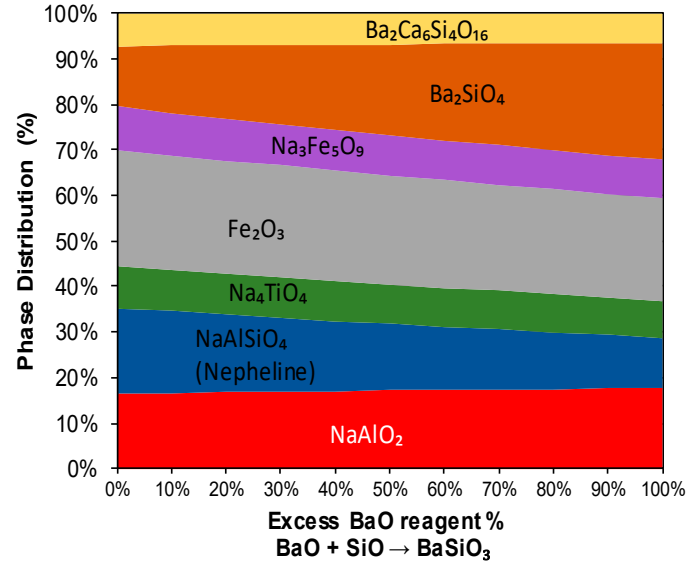

(a)

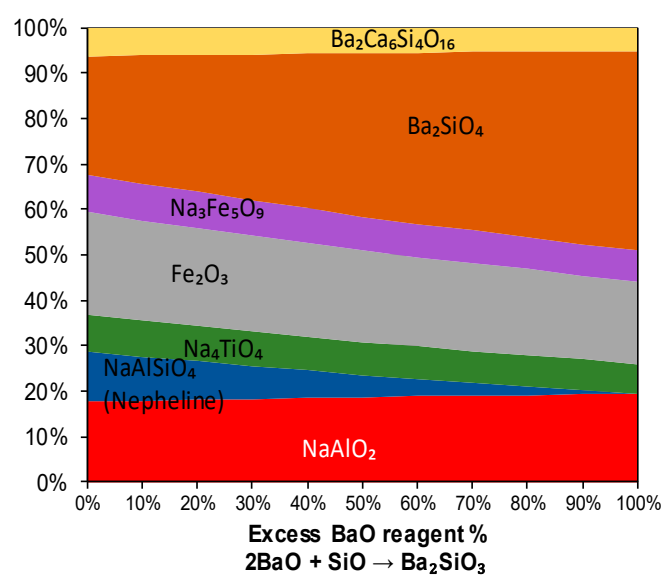

(b)

Figure 18. Thermodynamic predictions of sinter phase formation (a) when monobarium silicate is expected or $(\mathbf{b})$ when dibarium silicate is expected at excess of $\mathrm{BaO}$ additions at $50 \%$ excess soda, $900{ }^{\circ} \mathrm{C}$ for $2 \mathrm{~h}$.

Unlike calcium-added sinter system, where the addition of excess causes potential unwanted formation of grossular-type products that inhibit aluminum recovery, barium preferentially reacts with calcium during the sintering, leaving aluminum component to bind with sodium instead. Meher et al. reduced the amount of barium-to-silica mol ratio requirements to 1, and encouraging the formation of sodium barium silicate to allow for sodium and aluminum extraction ( $99 \%$ recovery) with decreased $\mathrm{BaO}$ reagent usage [39].

They also detected varying degrees of barium ferrite, $\mathrm{Ba}_{2} \mathrm{Fe}_{2} \mathrm{O}_{5}$ and $\mathrm{BaFe}_{12} \mathrm{O}_{19}$, and barium silicate products, as calcium is low in NALCO's bauxite residue system. In the AoG bauxite residue system, the addition of $20 \mathrm{~g} \mathrm{BaO}$ to $100 \mathrm{~g}$ bauxite residue (25\% excess to stoichiometric requirements to form $\mathrm{BaSiO}_{3}$ ), is investigated. XRD mineral identifications in Figure 19 indicates that batiferrite $\left(\mathrm{Ba}\left(\mathrm{Fe}_{10} \mathrm{Ti}_{2}\right) \mathrm{O}_{19}\right)$, ankangite $\left(\mathrm{BaTi}_{8} \mathrm{O}_{16}\right)$ and trasicite $\left(\mathrm{Ba}_{9} \mathrm{Fe}_{2} \mathrm{Ti}_{2} \mathrm{Si}_{12} \mathrm{O}_{3}(\mathrm{OH})\right)$ were the favorable phases that were formed experimentally, indicating that experimentally barium prefers to react with titanium instead. This indicates a selective titanium recovery into the sinters and residue, though iron's presence can result into the complex $\mathrm{Ba}-\mathrm{Fe}-\mathrm{Ti}$ product instead. It is recommended to combine barium with carbon reduction sintering to further improve the selectivity of $\mathrm{BaTi}_{8} \mathrm{O}_{16}$, as titanium could potentially be a valuable commercial product downstream.

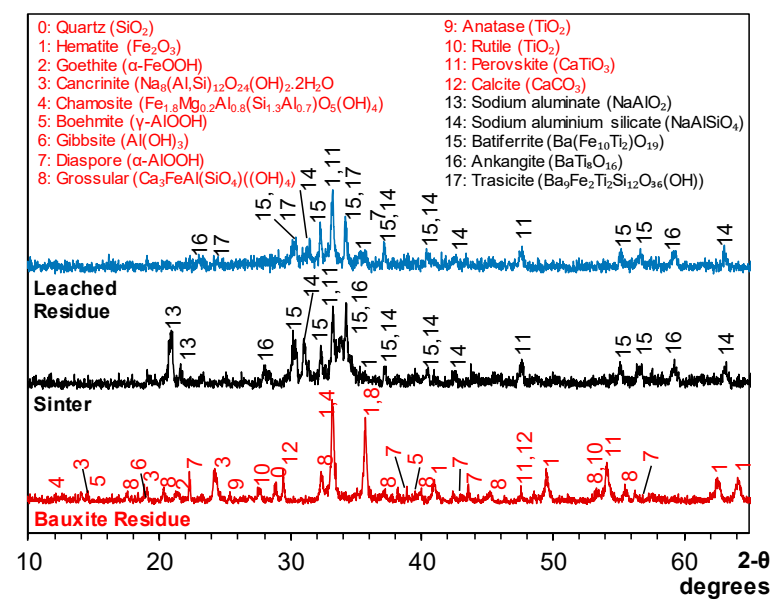

Figure 19. XRD of mineralogical phases for $\mathrm{BaO}$ additions (20 $\mathrm{g} \mathrm{BaO} / 100 \mathrm{~g}$ bauxite residue) at atmospheric conditions at $900{ }^{\circ} \mathrm{C}$ and for $2 \mathrm{~h}$. Red font: Existing minerals in bauxite residue; black font: Transformed sinter and leached minerals. 
In Figure 20, the SEM identification of barium titanate is visibly large tetragonal-type particles (1) with SEM empirical formula of $\mathrm{Ba}_{3.2} \mathrm{TiO}_{10}$, confirming barium affinity to titanium species. More complex agglomerates such as Figure 20 (2) that SEM empirical formula of the area is distributed as $\mathrm{BaTi}_{1.2} \mathrm{Fe}_{5.9} \mathrm{Ca}_{1.5} \mathrm{AlSi}_{1.5} \mathrm{O}_{24.3}$ and (3) as $\mathrm{Ba}_{3.7} \mathrm{Fe}_{3} \mathrm{Ca}_{1.2} \mathrm{AlSi}_{1.4} \mathrm{O}_{20.9}$ shows that there are partial losses of aluminum within the sinter product, though XRD only picks up trace amounts of existing sodium aluminum silicate as opposed to the complex product types.

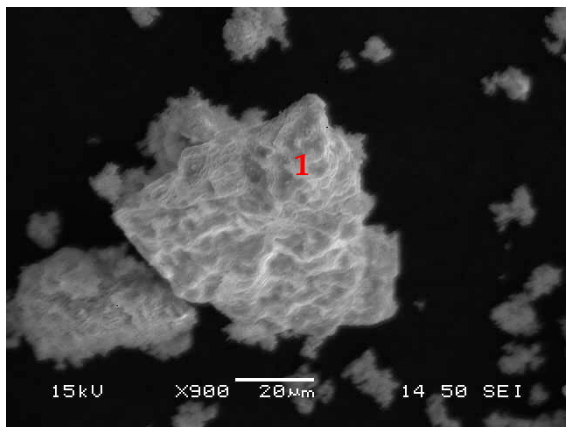

(a)

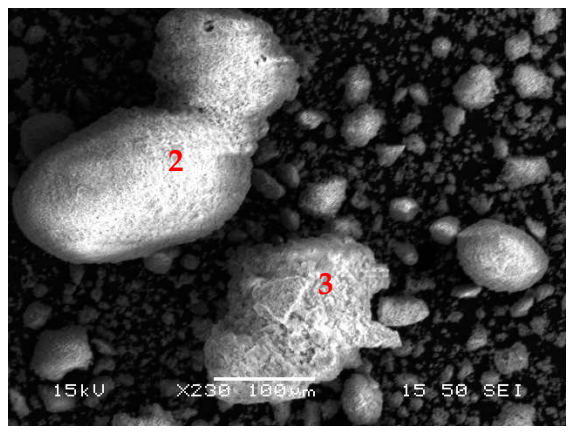

(b)

Figure 20. SEM mineral identifications in $\mathrm{BaO}, \mathrm{Na}_{2} \mathrm{CO}_{3}$ and bauxite residue (a) sinter products; (1) Barium titanate, and (b) Leached residue; (2) Barium titanium iron calcium aluminum silicon oxide

(3) Barium iron calcium aluminum silicon oxide (more details in Supplementary Materials).

\subsection{Experimental Results of Leaching Tests from 50\% Excess Soda Sinters with $\mathrm{CaO}, \mathrm{MgO}$ and BaO Additions}

The results of the leaching tests of $\mathrm{Na}_{2} \mathrm{CO}_{3}$ only system, $\mathrm{CaO}+\mathrm{Na}_{2} \mathrm{CO}_{3}$ system, $\mathrm{MgO}+\mathrm{Na}_{2} \mathrm{CO}_{3}$ system and $\mathrm{BaO}+\mathrm{Na}_{2} \mathrm{CO}_{3}$ system as shown in Figure 21, further confirms the outcomes of the thermodynamic and experimental analysis. Aluminum recovery of the systems was in the range of $64 \%$ to $75 \%$ in total, with the highest to lowest recovery coming from $\mathrm{BaO}>\mathrm{Na}_{2} \mathrm{CO}_{3}>\mathrm{MgO}>\mathrm{CaO}$ added systems. The co-recovery of silica was higher in both $\mathrm{Na}_{2} \mathrm{CO}_{3}$ only and $\mathrm{MgO}$ added system, at about $20 \%$, indicating that existence of partially leachable silica phases was formed during sintering. These phases were most like $\mathrm{Na}_{2} \mathrm{SiO}_{3}$ phase, as part of the soda added reacted preferentially with the available silica instead. In the $\mathrm{CaO}$ and $\mathrm{BaO}$ systems, the thermodynamically favourable formations of $\mathrm{Ca}_{2} \mathrm{SiO}_{4}$ and $\mathrm{Ba}_{2} \mathrm{SiO}_{4}$, and, the formation of a myriad of components such as sodium calcium silicate, grossular and garnet complex phases, locked silica into the matrix and hindered silica leaching from sinters.

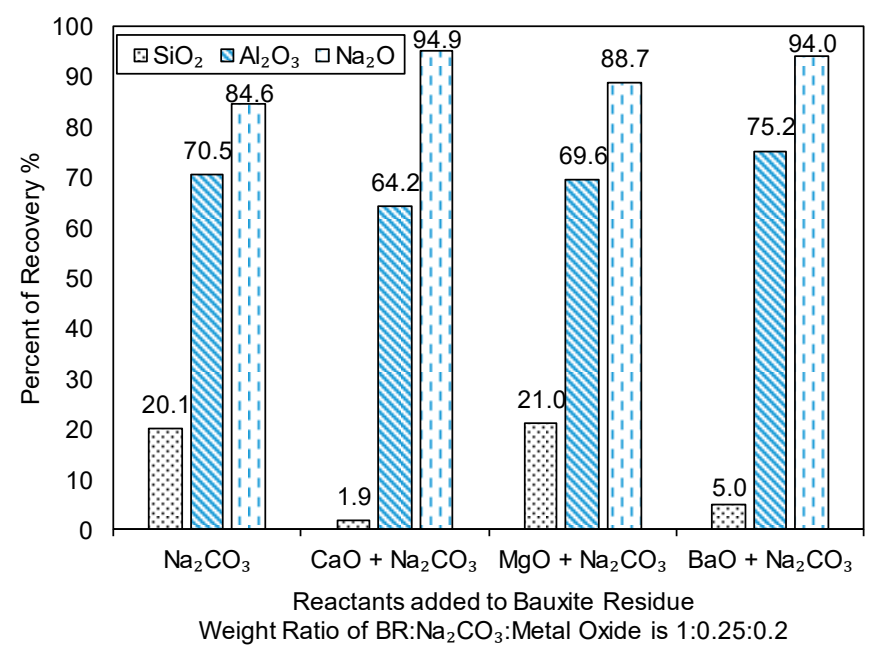

Figure 21. Results of experimental recovery of $\mathrm{Al}_{2} \mathrm{O}_{3}, \mathrm{SiO}_{2}$, and $\mathrm{Na}_{2} \mathrm{O}$ with $\mathrm{CaO}, \mathrm{MgO}$ and $\mathrm{BaO}$ added with $50 \%$ excess soda, compared to only $50 \%$ excess soda, $\mathrm{Na}_{2} \mathrm{CO}_{3}$, at $900{ }^{\circ} \mathrm{C}$ for $2 \mathrm{~h}$. 
The sodium recovery increased to $94 \%$ in systems that managed to stop silicon from turning into leachable products, whereas $\mathrm{Na}_{2} \mathrm{CO}_{3}$ only system exhibited the least amount of soda recovery. Barium oxide addition in the soda sintering system assisted the best recovery for both aluminum and sodium while suppressing silica in system, however, the price of barium oxide (US $\$ 300-\$ 500 /$ metric tonne) when compared to lime (US \$50-200/metric tonne), magnesium oxide (US \$80-\$200/metric tonne) and soda (US \$210-\$250/metric tonne), becomes considerably more expensive, for the aluminum and sodium recovered in bauxite residue.

A simplified mass balance of the laboratory scale experiment of optimised recovery at $50 \%$ excess soda (soda only) and stoichiometric carbon with $50 \%$ excess soda (carbon + soda) is presented in the flowchart (Figure 22) and mass balance (Table 3). The recovery of an optimised sintering process will be be $70 \%$ and $75 \%$ for aluminum $(0.2 \mathrm{~g} \mathrm{Al} / \mathrm{L})$ and $85 \%$ and $83 \%$ for sodium $(\sim 1 \mathrm{~g} \mathrm{Na} / \mathrm{L})$ for soda only system and carbon with soda system respectively. The recovery of silica is kept below $20 \%$ $(\sim 0.02 \mathrm{~g} \mathrm{Si} / \mathrm{L})$ when washed with solid-to-liquid ratio of 1:66. The leaching optimisation of the system is recommended to be investigated following this research. The proportion of leached residue to sinter product is $68.2 \%$ and $58 \%$ for soda only system and carbon with soda system respectively. The latter will experience higher gaseous carbon monoxide/dioxide losses and reduce $\mathrm{Fe}_{2} \mathrm{O}_{3}$ in residue into $\mathrm{FeO}$ or $\mathrm{Fe}_{3} \mathrm{O}_{4}$, and therefore decreasing load for downstream processing.

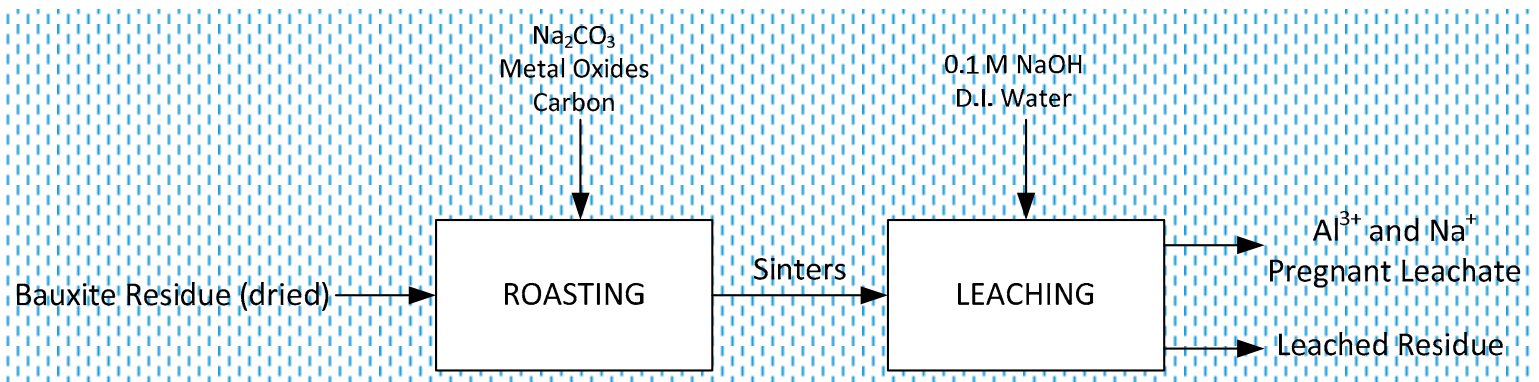

Figure 22. Total proposed flowsheet for the recovery of aluminum and sodium.

Table 3. Mass balance of input and output from sintering system (Soda only vs Carbon + Soda).

\begin{tabular}{cccccccc}
\hline $\begin{array}{c}\text { Mass Balance } \\
(\mathbf{k g})\end{array}$ & $\begin{array}{c}\text { Bauxite } \\
\text { Residue }\end{array}$ & $\mathbf{N a}_{2} \mathbf{C O}_{3}$ & Sinter & $\mathbf{C O}_{2} / \mathbf{C O}$ & $\mathbf{N a O H}$ & $\begin{array}{c}\text { Leached } \\
\text { Residue }\end{array}$ & $\begin{array}{c}\text { Metallurgical } \\
\text { Coke }\end{array}$ \\
\hline Soda only & 1 & 0.3 & 1.08 & 0.22 & 0.288 & 0.737 & - \\
\hline $\begin{array}{c}\text { Carbon }+ \\
\text { Soda }\end{array}$ & 1 & 0.3 & 0.905 & 0.318 & 0.288 & 0.6325 & 0.122 \\
\hline
\end{tabular}

\section{Conclusions}

The recovery of aluminum from Greek bauxite residue was found to reach a plateau of $70-75 \%$ when excess soda, retention time of sintering and temperature of sintering were investigated. This was confirmed in both thermodynamic and experimental results, whereas sodium recovery levels were optimized at $85-90 \%$. It is recommended that the minimum amount of soda reagent required to convert sodium and aluminum into leachable products, through this optimized study, should be used at $50 \%$ excess soda levels, aiding sodium-aluminum recoveries at feasible amounts and thus, processing and conditioning residue for use downstream.

Thermodynamic study of the bauxite residue notes that the type of complex desilication products that aluminum remains trapped in bauxite residue, such as sodium-based cancrinite or sodalite, or calcium-based grossular and garnet type product or cancrinite with calcium inclusions, transforms into equilibrium amounts of sodium aluminate and sodium aluminum silicates converted during sintering. Additional additives such as $\mathrm{CaO}, \mathrm{MgO}$ and $\mathrm{BaO}$ are also tested to consume silica from adhering to sodium and aluminum, forming other thermodynamically favourable and stable silica-bound species and liberating the main elements for recovery. 
The addition of barium oxide aids the recovery to achieve leachate containing $75 \%$ of recovered aluminum and $94 \%$ recovered sodium respectively while keeping silica levels suppressed. The presence of calcium existing in the Greek bauxite residue prevents the recovery of aluminum due to $\mathrm{NaAlSiO} / \mathrm{NaAlO}_{2}$ sintered equilibrium formations. Increased lime additions will preferentially react with iron in this system. Addition of carbon within inert conditions assisted aluminum recovery to $75 \%$ and sodium recovery to $83 \%$. The benefit of addition of carbon and in inert system, however, is to assist pre-reduction of iron and its recovery downstream. Optimal recovery of aluminum and sodium for Greek bauxite residue is recommended to be $70 \%$ and $85 \%$ respectively, when sintered with $50 \%$ excess stoichiometric $\mathrm{Na}_{2} \mathrm{CO}_{3}$.

Overall, soda sintering with other additional reagents may be more suitably adapted towards pure sodaline/cancrinite products as opposed to a calcium-rich desilication product. Depending on the different types of bauxite residues and desilication minerals present in it after Bayer processing, a mineral characterization and understanding of thermodynamic equilibrium system is important for the improved recovery of aluminum and sodium.

Supplementary Materials: The following are available online at http://www.mdpi.com/2075-163X/9/10/571/s1, In supplementary details titled "Additional Information_SEM Details"; EDS details for Figure 14: SEM mineral identifications in $\mathrm{CaO}, \mathrm{Na}_{2} \mathrm{CO}_{3}$ and bauxite, Figure 17: SEM mineral identifications in $\mathrm{MgO}, \mathrm{Na}_{2} \mathrm{CO}_{3}$ and bauxite, Figure 20: $\mathrm{SEM}$ mineral identifications in $\mathrm{BaO}, \mathrm{Na}_{2} \mathrm{CO}_{3}$ and bauxite residue.

Author Contributions: P.W.Y.T., D.P. and V.V. conceptualised and designed the experiments; P.W.Y.T. performed the experiments, writing and investigation; P.W.Y.T. performed XRD, Factsage 7.0 $0^{\mathrm{TM}}$, and SEM-EDS and analyzed the data. D.P. contributed to data validation, software training and further conceptualization of project. V.V. provided resources and project administration. D.P. provided supervision, funding acquisition, writing and project administration.

Funding: Research leading to these results has received funding from the European Community's Horizon 2020 Program ([H2020/2014-2019]) under Grant Agreement no. 636876 (MSCA-ETN REDMUD).

Acknowledgments: Special thanks to NTUA researchers Ioanna Giannoupoulou and Alexandra Alexandri; and AoG's team of helpers, Athina Dritsa and Athina Fillipou for experimental and analytical support and efforts and to the rest of the REDMUD team for the countless support. Constructive remarks by peer reviewers are greatly appreciated, as well to Koen Binnemans, Ken Evans, and György (George) Bánvölgyi for the support and thorough input for improving our work. This publication reflects only the author's view, exempting the Community from any liability. Project website: http://www.etn.redmud.org.

Conflicts of Interest: The authors declare no conflict of interest. The funding sponsors had no role in the design of the study; in the collection, analyses, or interpretation of data; in the writing of the manuscript, and in the decision to publish the results.

\section{References}

1. IAI. Current IAI Statistics: Alumina Production in Total for 2017. Available online: http://www.worldaluminum.org/statistics/alumina-production/ (accessed on 2 July 2018).

2. Mytilineos, S.A. Metallurgy. Available online: http://www.mytilineos.gr/en-us/metallurgy-and-mining/ activities (accessed on 3 July 2018).

3. Power, G.; Gräfe, M.; Klauber, C. Bauxite residue issues: I. Current management, disposal and storage practices. Hydrometallurgy 2011, 108, 33-45. [CrossRef]

4. Klauber, C.; Gräfe, M.; Power, G. Bauxite residue issues: II. options for residue utilization. Hydrometallurgy 2011, 108, 11-32. [CrossRef]

5. Alkan, G.; Schier, C.; Gronen, L.; Stopic, S.; Friedrich, B. A Mineralogical Assessment on Residues after Acidic Leaching of Bauxite Residue (Red Mud) for Titanium Recovery. Metals 2017, 7, 458. [CrossRef]

6. Borra, C.R.; Blanpain, B.; Pontikes, Y.; Binnemans, K.; Van Gerven, T. Recovery of Rare Earths and Major Metals from Bauxite Residue (Red Mud) by Alkali Roasting, Smelting, and Leaching. J. Sustain. Metall. 2017, 3, 393-404. [CrossRef]

7. Borra, C.R.; Blanpain, B.; Pontikes, Y.; Binnemans, K.; Van Gerven, T. Comparative Analysis of Processes for Recovery of Rare Earths from Bauxite Residue. JOM 2016, 68, 2958-2962. [CrossRef]

8. Avdibegovic, D.; Regadio, M.; Binnemans, K. Efficient separation of rare earths recovered by a supported ionic liquid from bauxite residue leachate. RSC Adv. 2018, 8, 11886-11893. [CrossRef] 
9. Evans, K. The history, challenges, and new developments in the management and use of bauxite residue. J. Sustain. Metall. 2016, 1-16. [CrossRef]

10. Smith, P. Reactions of lime under high temperature Bayer digestion conditions. Hydrometallurgy 2017, 170, 16-23. [CrossRef]

11. Mishra, B.; Gostu, S. Materials sustainability for environment: Red-mud treatment. Front. Chem. Sci. Eng. 2017, 11, 483-496. [CrossRef]

12. Bruckard, W.J.; Calle, C.M.; Davidson, R.H.; Glenn, A.M.; Jahanshahi, S.; Somerville, M.A.; Sparrow, G.J.; Zhang, L. Smelting of bauxite residue to form a soluble sodium aluminum silicate phase to recover alumina and soda. Trans. Inst. Min. Metall. Sect. C 2010, 119, 18-26. [CrossRef]

13. Kaußen, F.M.; Sofras, I.; Friedrich, B. Carbothermic reduction of red mud in an EAF and subsequent recovery of aluminum from the slag by pressure leaching in caustic solution. In Proceedings of the Bauxite Residue Valorisation and Best Practices (BR 2015), Leuven, Belgium, 5-7 October 2015; pp. 185-189.

14. Kaußen, F.M.; Friedrich, B. Methods for Alkaline Recovery of Aluminum from Bauxite Residue. J. Sustain. Metall. 2016, 2, 353-364. [CrossRef]

15. Tam, P.W.Y.; Xakalashe, B.; Friedrich, B.; Panias, D.; Vassiliadou, V. Carbothermic Reduction of Bauxite Residue for Iron Recovery and Subsequent Aluminum Recovery from Slag Leaching. In Proceedings of the 35th International Conference and Exhibition of The International Committee for Study of Bauxite, Alumina \& Aluminum (ICSOBA), Hamburg, Germany, 2-5 October 2017; pp. 603-613.

16. Dobos, G.; Horváth, G.; Felföldi, Z.; Karšulin, M.C.E.; Marušić, R.E. Complex utilization of red mud including the production of pig iron, sodium hydroxide, alumina and building material. In Travaux ICSOBA; Hungary, International Colloquium on Alumina Production from Low Grade Bauxites: Žiar nad Hronom, Slovakia, 1974; pp. 151-158.

17. Li, G.; Jiang, T.; Liu, M.; Zhou, T.; Fan, X.; Qiu, G. Beneficiation of High-Aluminum-Content Hematite Ore by Soda Ash Roasting. Min. Process. Extr Metall. Rev. 2010, 31, 150-164. [CrossRef]

18. Li, G.; Liu, M.; Rao, M.; Jiang, T.; Zhuang, J.; Zhang, Y. Stepwise extraction of valuable components from red mud based on reductive roasting with sodium salts. J. Hazard. Mater. 2014, 280, 774-780. [CrossRef] [PubMed]

19. Kaußen, F.M.; Friedrich, B. Soda Sintering Process for the Mobilisation of Aluminum and Gallium in Red Mud. In Proceedings of the Bauxite Residue Valorisation and Best Practices Conference (BR 2015), Leuven, Belgium, 5-7 October 2015; pp. 157-164.

20. Zheng, K.; Gerson, A.R.; Addai-Mensah, J.; Smart, R.S.C. The influence of sodium carbonate on sodium ahminosilicate crystallisation and solubility in sodium aluminate solutions. J. Cryst. Growth 1997, 171, 197-208. [CrossRef]

21. Bánvölgyi, G. Scale Formation in Alumina Refineries. In Proceedings of the 34th International Conference and Exhibition of The International Committee for Study of Bauxite, Alumina \& Aluminum (ICSOBA), St. Colomban, QC, Canada, 3-6 October 2016; pp. 101-114.

22. Rivera, R.M.; Ounoughene, G.; Borra, C.R.; Binnemans, K.; Van Gerven, T. Neutralisation of bauxite residue by carbon dioxide prior to acidic leaching for metal recovery. Min. Eng. 2017, 112, 92-102. [CrossRef]

23. Habashi, F. Karl Josef Bayer (1847-1904). In International Committee for Study of Bauxite, Alumina and Aluminum (ISCOBA), Movement of Scientists and the Production of Aluminum; ICSOBA Newsletter: St. Colomban, QC, Canada, 2015; pp. 9-13.

24. Dennis, W. Metallurgy: 1863-1963; Aldine Transaction: Piscataway, NJ, USA, 2010.

25. Alp, A.; Aydin, A.O. The Investigation of Efficient Conditions for Alumina Production from Diasporic Bauxites. Can. Metall. Q. 2002, 41,41-46. [CrossRef]

26. Alp, A.; Selim Goral, M. The effects of the additives, calcination and leach conditions for alumina production from red mud. Scand. J. Metall. 2003, 32, 301-305. [CrossRef]

27. Panias, D.; Paspaliaris, I. Boehmite Process-A New Approach in Alumina Production. Erzmetall 2003, 56, 75-81.

28. Wang, B.; Sun, H.-L.; Guo, D.; Zhang, X.-Z. Effect of $\mathrm{Na}_{2} \mathrm{O}$ on alumina leaching property and phase transformation of MgO-containing calcium aluminate slags. Trans. Nonferrous Metall. Soc. China 2011, 21, 2752-2757. [CrossRef] 
29. Kaußen, F.M.; Friedrich, B. Phase characterization and thermochemical simulation of (landfilled) bauxite residue ("red mud") in different alkaline processes optimized for aluminum recovery. Hydromet 2018, 176, 49-61. [CrossRef]

30. Smith, P. The processing of high silica bauxites-Review of existing and potential processes. Hydromet 2009, 98, 162-176. [CrossRef]

31. Meher, S.N.; Rout, A.K.; Padhi, B.K. Extraction of Alumina from Red Mud by Divalent Alkaline Earth Metal Soda Ash Sinter Process. Light Metals 2011, 2011, 231-236. [CrossRef]

32. Meher, S.N.; Padhi, B.K. A novel method for extraction of alumina from red mud by divalent alkaline earth metal oxide and soda ash sinter process. Int. J. Environ. Waste Manag. 2014, 13, 231-245. [CrossRef]

33. Raghavan, P.K.N.; Kshatriya, N.K.; Wawrynink, K. Recovery of Metal Values from Red Mud. In Light Metals 2011; Lindsay, S.J., Ed.; Springer International Publishing: Cham, Germany, 2016; pp. 103-106. [CrossRef]

34. Hertel, T.; Blanpain, B.; Pontikes, Y. A Proposal for a 100\% Use of Bauxite Residue Towards Inorganic Polymer Mortar. J. Sustain. Metall. 2016, 2, 394-404. [CrossRef]

35. Tathavadkar, V.; Jha, A.; Fülöp, T.; Török, T.I.; Rédey, A. A Comparison of the Mineralogical Characteristics and Alkali Roasting Behaviour of Red Mud of Different Origins. In Proceedings of the Global Symposium on Recycling, Waste Treatment and Clean Technology (REWAS 2004), Madrid, Spain, 26-29 September 2004; pp. 401-410.

36. Whittington, B.I. The chemistry of $\mathrm{CaO}$ and $\mathrm{Ca}(\mathrm{OH})_{2}$ relating to the Bayer process. Hydromet 1996, 43, 13-35. [CrossRef]

37. Gelencsér, A.; Kováts, N.; Turóczi, B.; Rostási, Á.; Hoffer, A.; Imre, K.; Nyirő-Kósa, I.; Csákberényi-Malasics, D.; Tóth, Á.; Czitrovszky, A.; et al. The Red Mud Accident in Ajka (Hungary): Characterization and Potential Health Effects of Fugitive Dust. Env. Sci Technol 2011, 45, 1608-1615. [CrossRef]

38. Mohapatra, B.K.; Mishra, B.K.; Mishra, C.R. Investigation of Alumina Discharge into the Red Mud Pond at NALCO's Alumina Refinery, Damanjodi, Orrisa, India. In Light Metals 2011; Lindsay, S.L., Ed.; The Minerals, Metals and Materials Society: Pittsburgh, PA, USA, 2011; pp. 93-96.

39. Meher, S.N.; Route, A.K.; Padhi, B.K. Recovery of Al and Na Values from Red Mud by BaO-Na $\mathrm{CO}_{3}$ Sinter Process. J. Chem. 2011, 8, 1387-1393. [CrossRef]

40. Meher, S.N.; Padhi, B.K. Effects of $\mathrm{MgO}$ and $\mathrm{Na}_{2} \mathrm{CO}_{3}$ Additives, Sintering Temperature and Leaching Conditions for Extraction of Alumina from Bayer's Process Waste Residue (Red Mud). Chem. Sci. Trans. 2012, 1, 456-462. [CrossRef]

41. Vind, J.; Malfliet, A.; Bonomi, C.; Paiste, P.; Sajó, I.E.; Blanpain, B.; Tkaczyk, A.H.; Vassiliadou, V.; Panias, D. Modes of occurrences of scandium in Greek bauxite and bauxite residue. Min. Eng 2018, 123, 35-48. [CrossRef]

42. Sajó, I.E. XDB Powder Diffraction Phase Analytical System, Version 3.0, User's Guide; Aluterv-FKI: Budapest, Hungary, 2005.

43. Hodge, H.; Tam, P.W.Y.; Vaughan, J.; Panias, D. Bauxite Residue Sinter Phase Transformations. In Proceedings of the 5th International Slag Valorisation Symposium, Leuven, Belgium, 3-5 April 2017.

44. Meher, S.N. Alumina extraction from red mud by $\mathrm{CaCO}_{3}$ and $\mathrm{Na}_{2} \mathrm{CO}_{3}$ sinter process. Int. J. Chem. Stud. 2016, 4, 122-127.

(C) 2019 by the authors. Licensee MDPI, Basel, Switzerland. This article is an open access article distributed under the terms and conditions of the Creative Commons Attribution (CC BY) license (http://creativecommons.org/licenses/by/4.0/). 